\title{
Paleomagnetic Results from Archaeological Sites in Argentinean Patagonia: Evidence for the Holocene Geomagnetic Excursions in Southern South America and Its Chronostratigraphic Implications
}

\author{
Hugo G. Nami \\ Department of Geological Sciences, Laboratory of Geophysics “Daniel A. Valencio”, CONICET-IGEBA, FCEN, UBA, \\ Buenos Aires, Argentina \\ Email: hgnami@fulbrightmail.org
}

How to cite this paper: Nami, H. G. (2019). Paleomagnetic Results from Archaeological Sites in Argentinean Patagonia: Evidence for the Holocene Geomagnetic Excursions in Southern South America and Its Chronostratigraphic Implications. Archaeological Discovery, 7, 127-154. https://doi.org/10.4236/ad.2019.72008

Received: March 21, 2019

Accepted: April 25, 2019

Published: April 28, 2019

Copyright $\odot 2019$ by author(s) and Scientific Research Publishing Inc. This work is licensed under the Creative Commons Attribution International License (CC BY 4.0).

http://creativecommons.org/licenses/by/4.0/

\begin{abstract}
Detailed palaeomagnetic research performed in archaeological and paleontological sites in southern South America yielded a number of highly fluctuating paleosecular variation records with geomagnetic field excursion(s) during the Holocene. To assess this topic a variety of sections of recent sediments were sampled. In the case presented here they belong from diverse continental sedimentary sequences formed in coastal marine and cave's environments. Paleomagnetic samplings were performed in several deposits in San Blas Bay and Pali Aike areas, respectively located in the northern and southern parts of Argentinean Patagonia region. To collect samples, cylindrical plastic containers $2.5 \mathrm{~cm}$ long and $2 \mathrm{~cm}$ diameter were carefully pushed into the sections, overlying each other by about 50 percent. Their strike and dip were measured using a Brunton compass and inclinometer; they were consolidated with sodium silicate after removal and numbered from top to bottom. All samples were subjected to progressive AF demagnetization in steps of $3,6,9,12,15$, $20,25,30,40$ and $60 \mathrm{mT}$ in a 3 -axis static degausser attached to a $2 \mathrm{G}$ cryogenic magnetometer. Additional steps from 80 to $120 \mathrm{mT}$ were used in some samples. Characteristic remnant magnetization was calculated using principal-components analysis, with the best-fitting line going to the origin in the Zijderveld diagrams. In general, maximum angular deviations were generally within low values. Some samples had univectorial behavior, while some showed two or three components. Most of the sections show normal and intermediate polarity directions far from the present GF, while reversed polarities were recorded at San Blas 2, La Serranita 1 and Punta Rubia 2 sites in San
\end{abstract}


Blas Bay as well Saenz cave in the Pali Aike area. They show similar directions observed in nearby sites from southern Patagonia in Argentina and Chile. In fact, previous results obtained at Mylodon, Cueva del Medio, Don Ariel and Las Buitreras caves yielded remanence directions corresponding to obliquely normal, obliquely reversed and reversed field polarity directions with similar VGPs. This situation strengthens the hypothesis of the existence of the Mylodon excursion in southern Patagonia. On the other hand, the presence of intermediate and reverse VGPs in San Blas records and other sites also supports its regional extent in the southern cone of South America. If the presented paleomagnetic features are true GMF behavior, the remarkably PSV record can serve to correlate regional stratigraphies, and to determine relative and absolute chronologies. Besides, if the anomalous directions represent excursions, they may be also used as dating devices, becoming excellent magnetostratigraphic markers for the time-span covered by the paleomagnetic record of the sites presented in this paper.

\section{Keywords}

Paleomagnetism, Geomagnetic Excursions, Archaeological Sites, Holocene, South America, Argentina

\section{Introduction}

Shared by the Republics of Argentina and Chile, Patagonia is a large geographic region of $\sim 1,000,000 \mathrm{~m}^{2}$ located in the southern end of South America. The Argentine portion of Patagonia is placed south of Colorado River and includes the provinces of Neuquén, Río Negro, Chubut and Santa Cruz, as well as the eastern portion of Tierra del Fuego Island and the southernmost part of Buenos Aires province. The Chilean part is located south of Bío Bío River and comprises the southern provinces and regions of Aisén and Magallanes, including the west of Tierra del Fuego and Cape Horn, and Palena Province in Los Lagos Region.

For a long time, this region was subjected to a significant number of Cenozoic palaeomagnetic investigations (Ré et al., 2008). Specific research on terminal Pleistocene and Holocene paleosecular variations records obtained at sedimentary lacustrine deposits in Argentina has been a topic since the early eighties (e.g., Creer et al., 1983; Gogorza et al., 1998, 2000; Sinito \& Nuñez, 1997; Sylwan, 1989; Valencio et al., 1985). Detailed studies performed in archaeological and paleontological sites in Patagonia have yielded a number of results with stable and unstable records that showed intermediate and reverse geomagnetic field (GF) directions during the last $\sim 11 / 10 \mathrm{ky}$, suggesting that GF excursion(s) occurred at different times through the Holocene (Nami, 1995a, 1999a, 2011, 2012; Nami \& Sinito, 1991, 1993, 1995; Nami et al., 2017; Sinito et al., 2001). The possibility of an anomalous GF behavior during the more recent epoch seems to be an interesting palaeomagnetic subject, with important geomagnetic implications. The identification and definition of geomagnetic excursions have several re- 
quirements (Laj \& Channell, 2007; Roberts, 2008); one of the main ones in its distinction is the recording of similar behavior of the GF feature in diverse types of materials, such as lava flows, lacustrine sediments, and continental sedimentary deposits. Specifically, results obtained from the latter ones must belong to several sites and preferably in different environments (Thouveny et al., 1985; Verosub \& Banerjee, 1977; Watkins, 1972). Hence, to assess this topic a variety of sections of recent sediments were sampled. Resulting from their study, this paper reports the results of a detailed palaeomagnetic research performed in archaeological and geological sections corresponding to Holocene deposits. They belong from diverse continental sedimentary sequences mainly formed in coastal marine and cave's environments. Paleomagnetic samplings were carried out in San Blas Bay and Pali Aike, which are areas located at the northern and southern portions of Argentine Patagonia, respectively.

\section{Sampling Sites and Age of Deposits}

To check results previously obtained, samplings were carried out in sections of fine sediments corresponding to the epoch under consideration. They were performed in the northern coast of Patagonia (Patagones Department) SE Buenos Aires province; also at the Gallegos-Chico River basin (Güer Aike Department), southern Santa Cruz province (Figure 1). Sampling sites were as follows:

1) San Blas 2 (SB2) $\left(40^{\circ} 33.39^{\prime} \mathrm{S}, 62^{\circ} 14.35^{\prime} \mathrm{W}\right)$ is placed at San Blas village, Jabalí Island, in the Atlantic Ocean coast. The sampling $(n=36)$ was carried out in a section exposed on the entrance road to the village. It showed five stratigraphic levels; three of them are fine sediments (numbered I to III) while the other ones, are two gravel layers, named as I and II. Gravel I is located under the vegetation and gravel II of about $16 \mathrm{~cm}$ thick, is between $0.94-1.10 \mathrm{~m}$ below the surface. Layer I is sandy brown pale sediment, II is a more compacted sandy gray level and III is reddish sand, located below gravel II. The samples were taken as follows: In level I (samples SB2 1 to SB2 18), level II (SB2 19 to SB2 26) and the upper portion of level III (SB2 27 to SB2 36). A sample of re-deposited shell coming from gravel II yielded an uncalibrated ${ }^{14} \mathrm{C}$ date of $9720 \pm 220$ years before present (BP) (LP-1006); other ${ }^{14} \mathrm{C}$ dates on gravel deposits from Jabalí Island yielded ages of $\sim 5.3 \mathrm{ky}$ BP (Trebino, 1987). The gravel layer was probably formed at the time of the Holocene marine ingression that exhibited the maximum level between 6 and $5 \mathrm{ky} \mathrm{BP}$ in the eastern coast of South America in general (Pirazzolli, 1996), particularly in the Buenos Aires province (Violante et al., 2001).

2) Punta Rubia 2 (PR2) $\left(40^{\circ} 46.0^{\prime} \mathrm{S}, 62^{\circ} 16.02^{\prime} \mathrm{W}\right)$ is situated on the Atlantic Ocean shoreline at $\sim 20 \mathrm{~km}$ south of SB2. Over the coastal cliff there are a number of archaeological shell mounds that were impacted by diverse natural process, mainly the wind erosion. There, a number of sites were sampled for paleomagnetic research; one of them is an eroded shell midden called here PR2. A test pit of $1 \mathrm{~m}^{2}$ by $1 \mathrm{~m}$ depth was performed for archaeological purposes. It showed three stratigraphic levels: I was formed by sand, layer II is reddish brown 


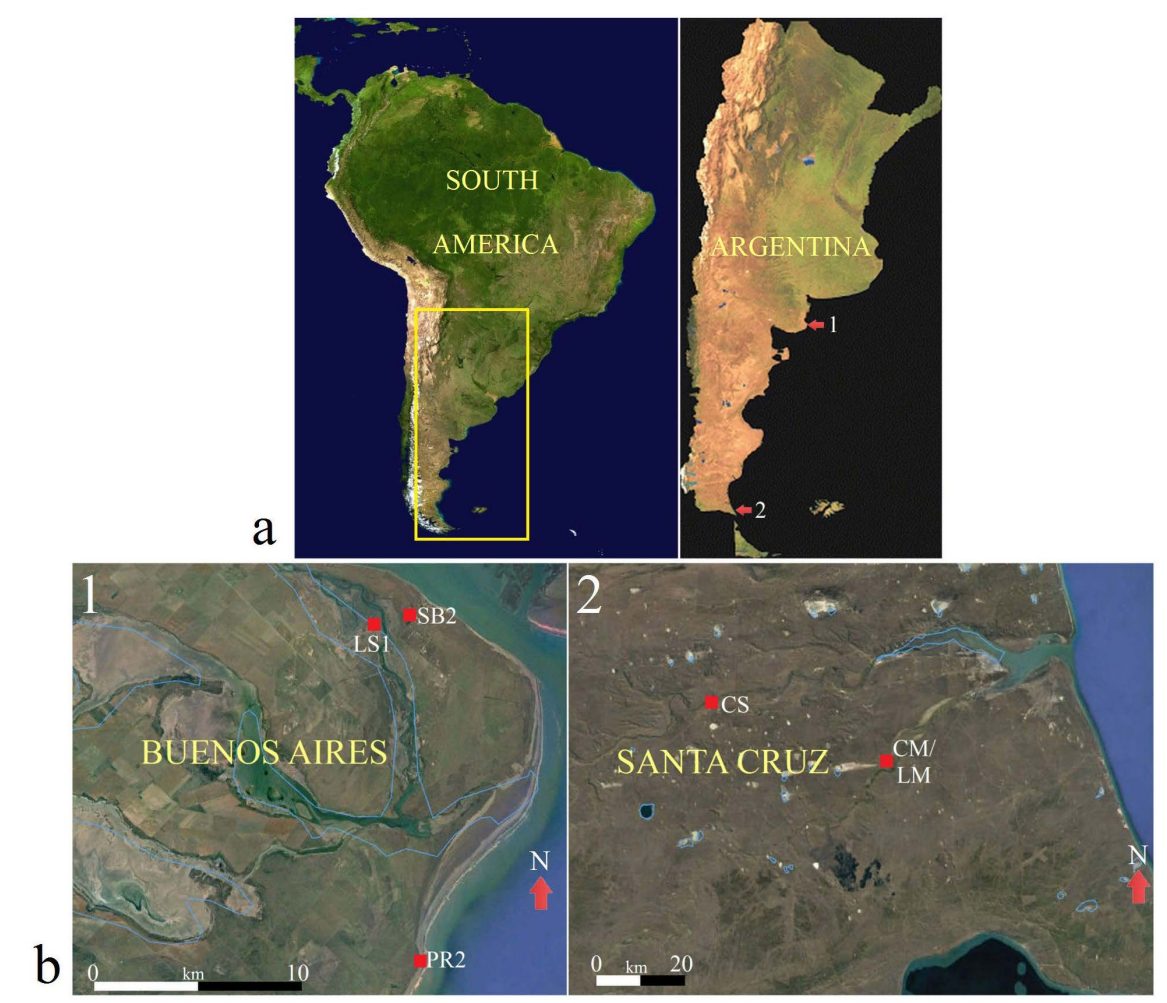

Figure 1. Geographical location of the sites reported in this paper. (a) Map of South America showing the location of Argentina Republic (denoted with a rectangle) indicating with numbers the place of the sampled sites; (b) Localities and sites showed in the general map: 1) San Blas bay in Buenos Aires province, 2) Pali Aike region in the Santa Cruz province (modified after Google maps).

clayed sediment and III is gray clay. Archaeological artifacts corresponding to the Late Holocene were found in the surface and the upper part of level II. A vertical sampling $(n=39)$ along the section of the test pit was carried out. Samples PR2 1 to PR2 16 belongs from level I, PR2 17 to PR2 34 from level II and PR2 35 to PR2 39 from level III.

3) La Serranita 1 (LS1) $\left(40^{\circ} 33.02^{\prime} \mathrm{S}, 62^{\circ} 38.16^{\prime} \mathrm{W}\right)$ is located $\sim 3 \mathrm{~km}$ to the West of San Blas village on a chain of sand dunes overlying a gravel deposit indicating a Middle Holocene coastal line dated $\sim 6.0$ ky BP (Trebino, 1987). At La Serranita locality, a number of archaeological shell middens are exposed with remains over the surface and partially buried deposits. Careful examinations of one of them allowed finding diverse archaeological remains. It is worth to mention Middle Holocene triangular projectile points, lithic artifacts, mollusks, varied faunal remains and a hearth that was carefully excavated. Using conventional ${ }^{14} \mathrm{C}$ method at the LATYR laboratory, University of La Plata (Argentina) a charcoal sampled for the hearth was dated at $5300 \pm 40$ uncalibrated years BP. Mollusks remains were also dated at $5310 \pm 70$ and $5320 \pm 60$ years BP (Sanguinetti de Bórmida, 2005). After finished the hearth excavation, a horizontal paleomagnetic sampling $(\mathrm{n}=15)$ was performed on a sand deposit at $5 \mathrm{~cm}$ below the hearth.

4) Cueva Montecarlo (CM) $\left(51^{\circ} 54.86^{\prime} \mathrm{S}, 69^{\circ} 38.79^{\prime} \mathrm{W}\right)$ is a small cave formed in 
an ancient crater called Montecarlo hill at $\sim 1 \mathrm{~km}$ west of Markatch Aike ranch, in the Gallegos-Chico River basin, south of Santa Cruz province, southern Patagonia (Nami, 1995b, 1999b). Underlying the bedrock, the deposit of $\sim 0.4 \mathrm{~m}$ has three layers: layer 1 is sheep dung, 2 is silt (Bayarski, pers.com), and 3 is mostly formed by ash charcoal product of human hearths. This layer contains a notably archaeological level with stone tools used by hunter-gatherers living in the area during the late Holocene (Bird, 1988; Nami, 1995b). A conventional ${ }^{14} \mathrm{C}$ date obtained at $50 \mathrm{~cm}$ from the ash layer yielded a date of $1040 \pm 50$ uncalibrated years BP (Beta-124706). Twelve paleomagnetic samples in two section named CM1 $(n=6)$ and CM2 $(n=6)$ were made in layers 2 (samples 1 to 3 ) and 3 (samples 4 to 6).

5) Laguna Montecarlo (LMo) $\left(51^{\circ} 55^{\prime} \mathrm{S}, 69^{\circ} 39^{\prime} \mathrm{W}\right)$ is a small temporary lagoon located at $2.5 \mathrm{~km}$ west from CM. To check the records obtained from archaeological sites from the region, a $1 \mathrm{~m}^{2}$ trial pit by $0.9 \mathrm{~m}$ depth was made in center of the lagoon. Only one stratum of a uniform grayish green clay was sampled (n = 23) up to $52 \mathrm{~cm}$ depth. The Holocene age of the deposit may be suggested because these sort of small lagoons have been regionally formed after the post glacial times (Grondona, 1975).

6) Cueva Saenz (CS) $\left(51^{\circ} 44.46 \mathrm{~S}, 70^{\circ} 09.92^{\prime} \mathrm{W}\right)$ located $60 \mathrm{~km}$ to the west of the Río Gallegos city. This cave is located $400 \mathrm{~m}$ east of Las Buitreras cave, which was previously sampled (Nami, 1999a). Two palaeomagnetic samplings were performed in two parts of the site with different sedimentary deposits; one in the front part and the other in the inner portion. In this paper, is reported only the preliminary results obtained in the cores $(n=5)$ taken from a $\sim 30 \mathrm{~cm}$ sand level deposit located in the frontal part.

\section{Paleomagnetic Study}

\section{Sampling, Methods, and Results}

With exception of LS1 that the sampling was horizontally performed, all samplings were done in vertical form from the top to the base of the sedimentary deposits (Figure 2(e)). Samples were collected using $2.5 \mathrm{~cm}$ long and $2 \mathrm{~cm}$ diameter plastic containers carefully pushed into the sediments and overlying the next one about $50 \%$ each. Their orientation was measured using a Brunton compass; they were consolidated with sodium silicate once removed and finally, numerated from the top to the bottom. In some cases samples were not taken near the surface because the sediments were unconsolidated and they may have been disturbed by recent events, such as animal and/or human trampling (PR2, $\mathrm{CM}$ ), the upper part might be disturbed by roots (SB2) or, because the presence of pebbles and rocks (CS).

All samples were subjected to progressive AF demagnetization in steps of 3,6, $9,12,15,20,25,30,40$ and $60 \mathrm{mT}$ in a 3 -axis static degausser, attached to a $2 \mathrm{G}$ cryogenic magnetometer and subsequently measured with the magnetometer. Additional steps of 80, 100 and $120 \mathrm{mT}$ were used in some samples. Characteristic 

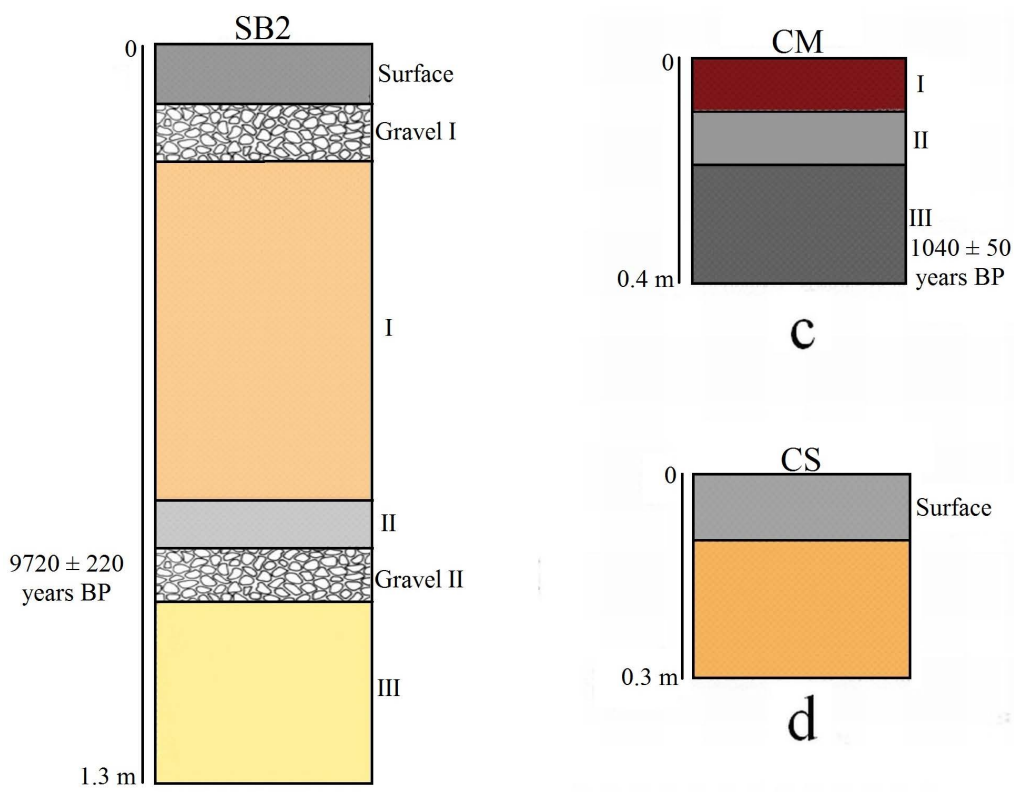

C

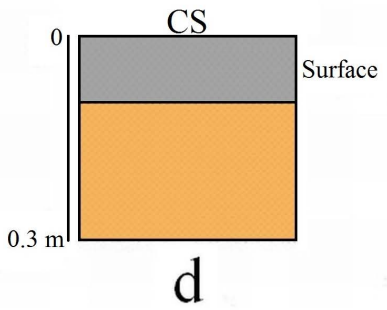

a
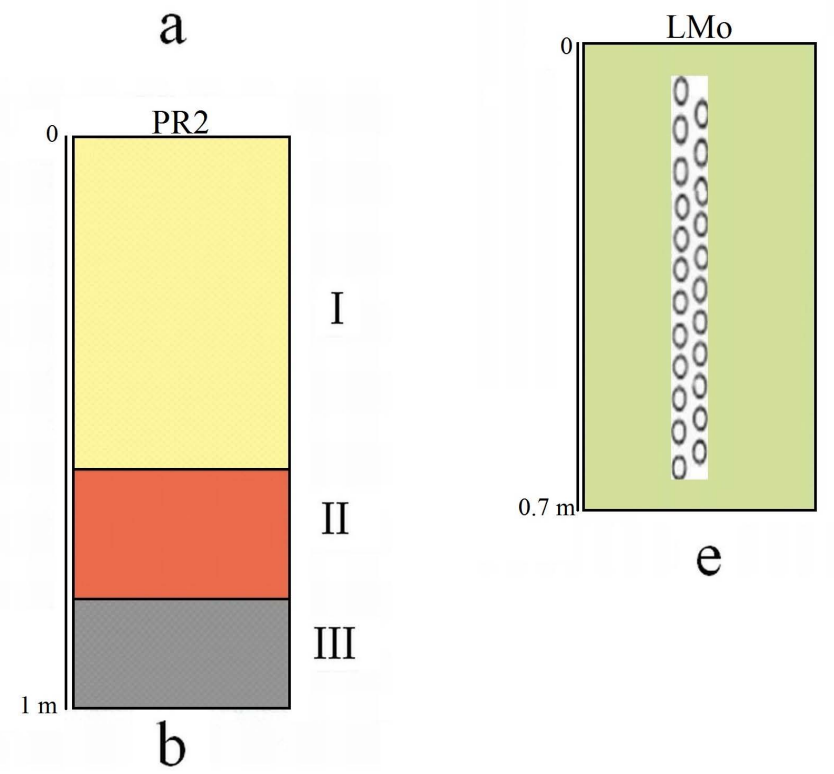

Figure 2. Schematic profiles showing the stratigraphic sections sampled related with ${ }^{14} \mathrm{C}$ dates. (a) San Blas 2; (b) Punta Rubia 2; (c) Cueva Montecarlo; (d) Cueva Saenz; (e) Laguna Montecarlo showing the paleomagnetic sampling. Numbers to the right of the sections show numbers of layers, its sediments description and samples locations are given in the text.

remanent magnetization (ChRM) was calculated using Principal Components Analysis (PCA). The inherent scatter in directions was measure using the Maximum Angular Deviation (MAD) (Kirschvink, 1980).

According to the number of magnetic components and stability, remanence directions in most palaeomagnetic samples were highly reliable (HRe), with practically univectorial behavior with decay towards the origin (i.e. SB2 16, Figure 3(c); CM 12, Figure 6(a); LMo 10, Figure 7(d)) and moderately reliable (MRe), with noisy behavior during demagnetization and/or, well defined prin- 
cipal component but with erratic behavior during final steps (i.e. SB2 3, SB2 8 , Figure 3(a), Figure 3(b)) unreliable, with unstable behavior (e.g. Figure 16); in this case, they were rejected (SB2 11, LS1 4, LS1 10). In general samples from each site showed a common pattern with similar reliability. They are as follows:

SB2: Vector diagrams projection (VDP) depicted in Figure 3 illustrates samples that showed a viscous remanence which was removed at $3-12 \mathrm{mT}$ (e.g. SB2 3, SB2 16, Figure 3(a), Figure 3(c)). The ChRM show cores with normal directions with either steep (SB2 16, Figure 3(c)) or shallow negative inclinations (SB2 8, Figure 3(b)). A few samples showed southward directions (SB2 23, Figure $3(d))$.

PR2: Most of the samples were HRe with linear decay towards the origin (PR2 14, PR2 18, Figure 4(a), Figure 4(b)). VDP diagrams illustrated in Figure 4 show specimens with either single component (PR2 14, PR2 18, Figure 4(a) \& Figure 4(b)) and with the anchored line of some of them decaying to the origin (PR2 24, Figure 4(d)); others ones had two components, one with an anomalous southward direction (PR2 24, Figure 4(b), Figure 4(d)). Zijderveld diagrams show reverse samples (PR2 18, PR2 24, Figure 4(b), Figure 4(d)) and normal with either shallow (PR2 19, Figure 4(c)) or steep inclinations with north-easterly (PR2 36, Figure 4(e)).

LS1: Samples from this site showed a common pattern with similar magnetic behavior. Many of them presented linear demagnetization plots with one of two magnetic components (Figure 5). In the majority, a ChRM could be defined trending in the Zijderveld diagrams towards the origin. More secondary components were a soft viscous magnetism that was easily eliminated between 3 and $9 \mathrm{mT}$ (LS1 9, LS1 13, Figure 5(b) \& Figure 5(c)). In most LS1 cores the NRM

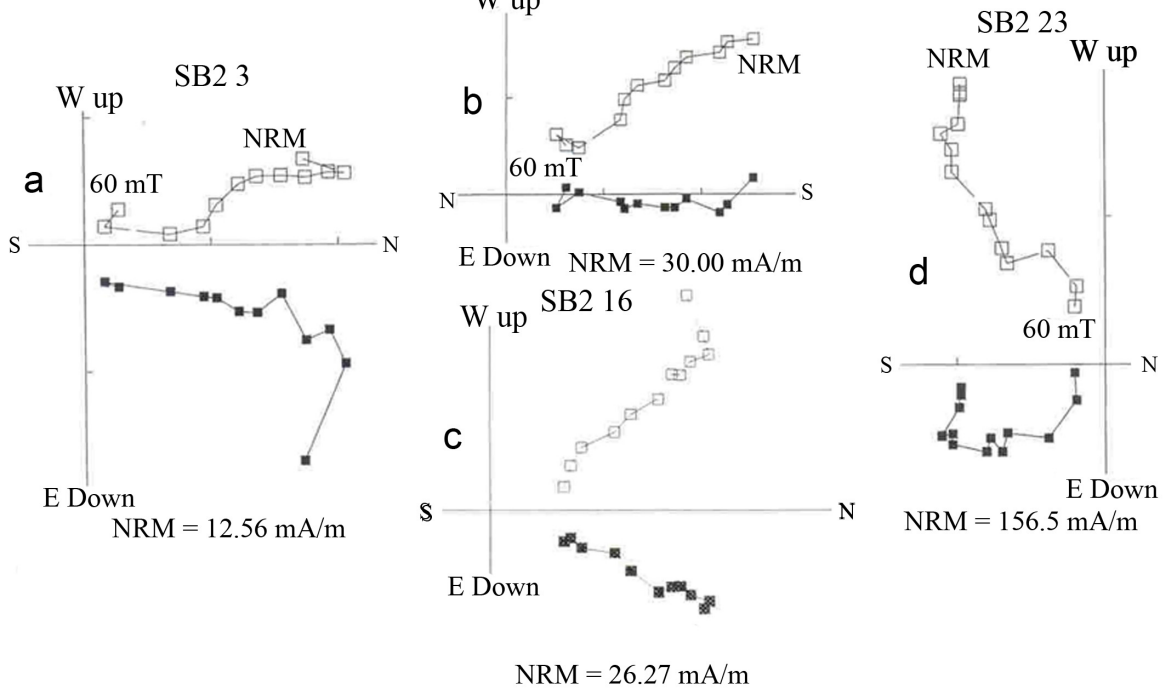

Figure 3. Typical Zijderveld diagrams from the SB2 section. The totality of the vector projection diagrams illustrated in the figures is directional data with corrected field. Solid symbols correspond to the projection onto the horizontal plane, while open symbols are projection onto the vertical plane. 

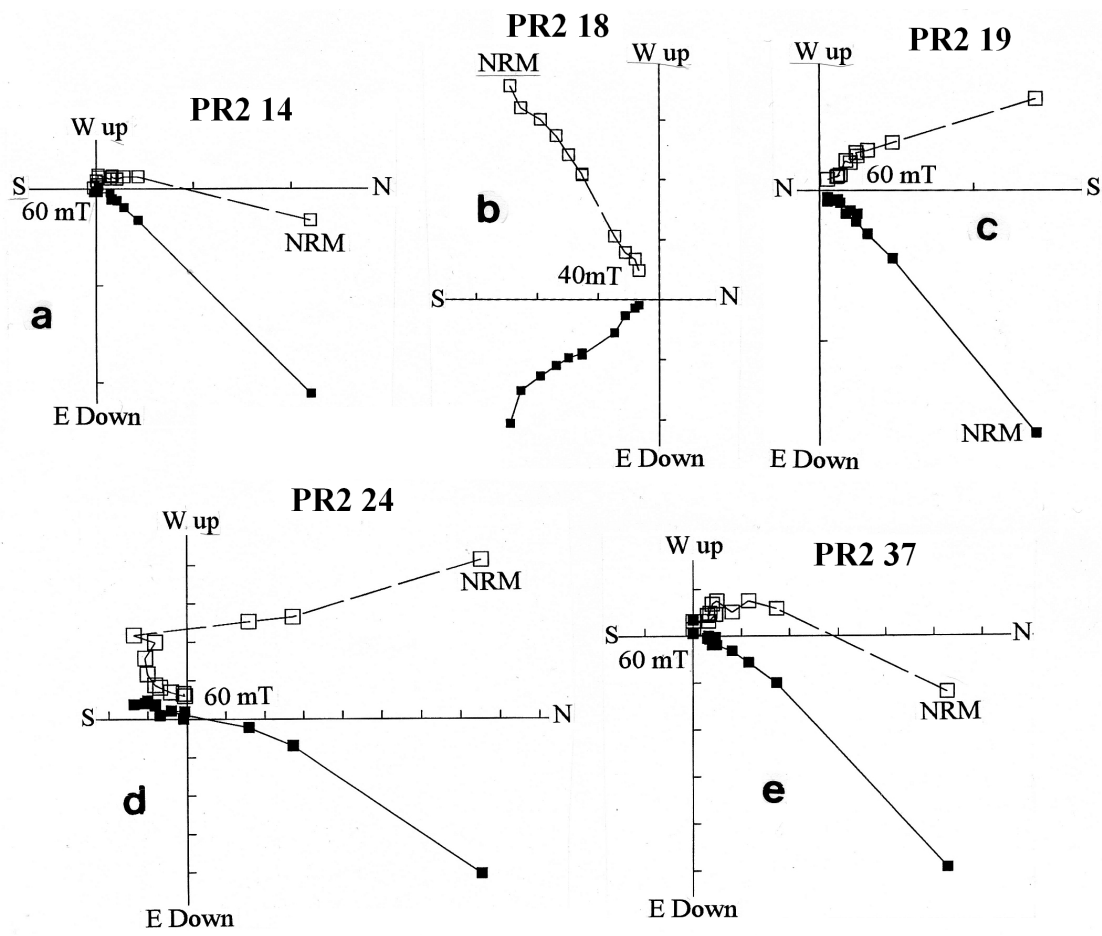

Figure 4. Vector components diagrams showing the behavior of typical samples from PR2 profile.
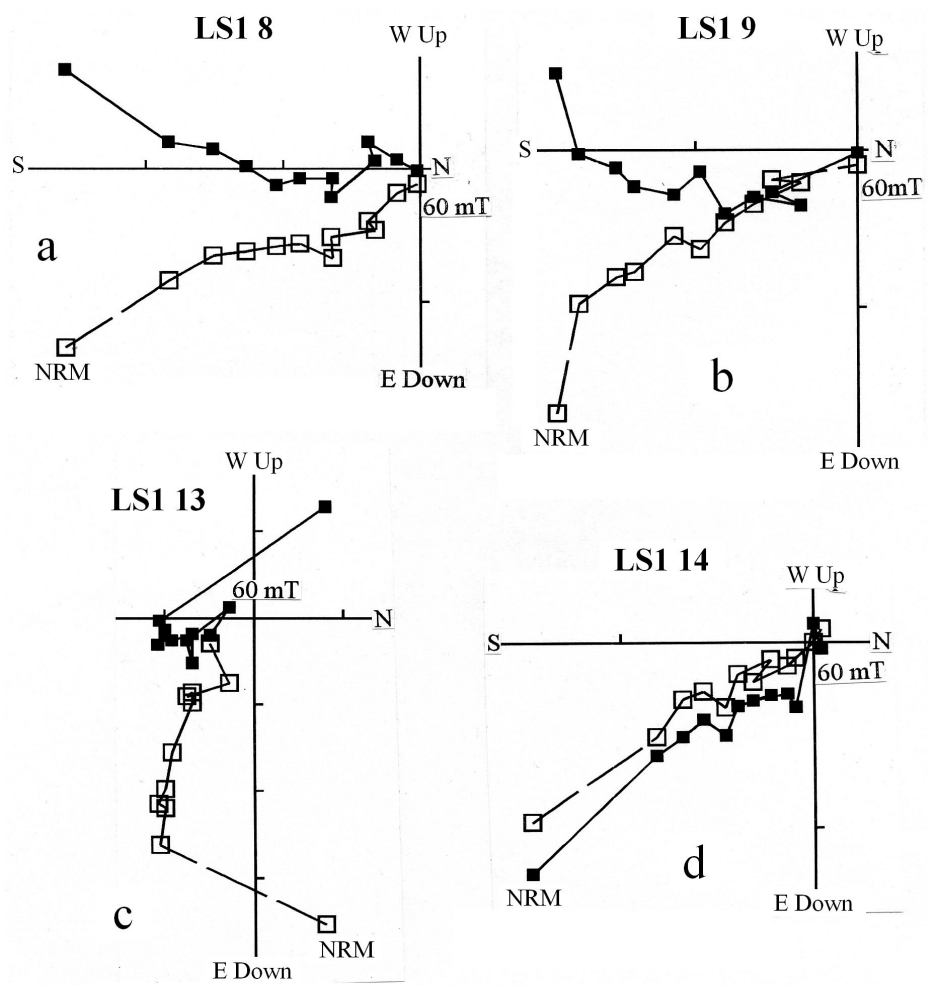

Figure 5. Zijderveld diagrams of some samples from LS1.

removed at fields of $60 \mathrm{mT}$ (Figure 5). LS1 14 (Figure 5(d)) are examples of specimens with univectorial behavior with decay towards the coordinates origin. 
CM: Specimens from this site showed similar magnetic behavior with linear demagnetization plots with one of two magnetic components. In the majority, a ChRM could be defined trending in the Zijderveld diagrams towards the origin (CM1 2, CM1 4, CM2 1, Figure 6(a), Figure 6(b), Figure 6(d)). More secondary components were a soft viscous magnetism that was easily removed between 3 and 12 mT (CM1 3, CM2 4, Figure 6(b), Figure 6(f)). Normal and intermediate directions (CM1 2, Figure 6(a)), were found in several samples. In most CM cores less than $10 \%$ of the NRM eliminated at fields of $60-80 \mathrm{mT}$ (CM1 2, CM2 2, Figure 6(a), Figure 6(e)). CM1 2, CM1 4 CM2 1 (Figure 6(a), Figure 6(c), Figure 6(d)) exemplify cores with univectorial behavior decaying towards the coordinate's origin with normal directions (CM1 2, CM1 4, CM2 1, Figure 6(a), Figure 6(c), Figure 6(d)), and low inclination values (CM2 1, CM2 4, Figure 6(d), Figure 6(f)). A few samples had two components with the second one decaying to the origin in the VDP (CM2 2, CM2 4, Figure 6(e), Figure 6(f)). Some isolated cores showed three components, one of them going to the origin with southwesterly direction (CM1 3, Figure 6(b)).

LMo: The majority of the samples were highly reliable single components, displaying similar pattern going to the origin in the Zijderveld diagrams (LMo 12, LMo 16, LMo 29, Figure 7(b), Figure 7(d), Figure 7(e)). Some samples had univectorial behavior with south- and north-westerly (LMo 8, LMo 21, Figure 9(b), Figure 9(e)) and westerly directions (LMo 1, LMo 9, LMo 10, Figure 7(a), Figure 7(c), Figure 7(d)).

CS: The samples showed either single component remanence (CS 5, Figure 8(b)) and other ones had two magnetic components with anchored fitting line to the origin in the VDP diagrams; some cores showed a viscous remanence removed at $3 \mathrm{mT}$ (CS 1, Figure 8(a)). They recorded univectorial reverse (CS 16, Figure 8(b)) and intermediate (CS 5, Figure 8(a)) directions.

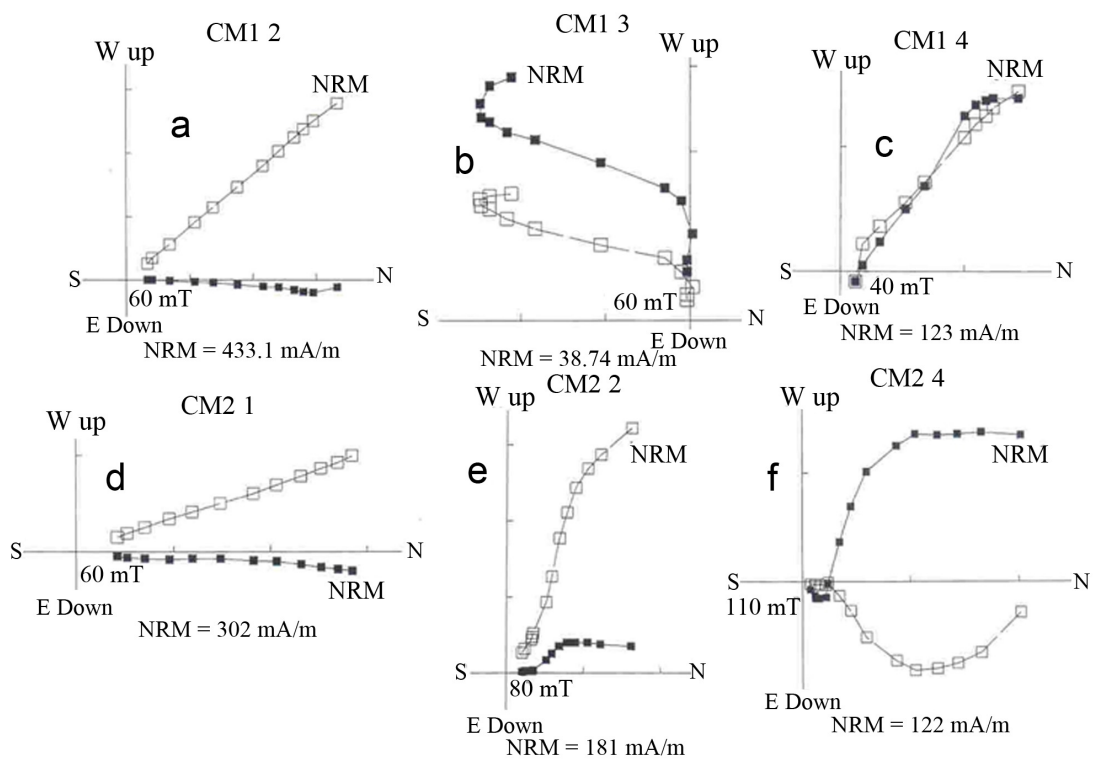

Figure 6. Examples of vector projection diagrams for CM site. 


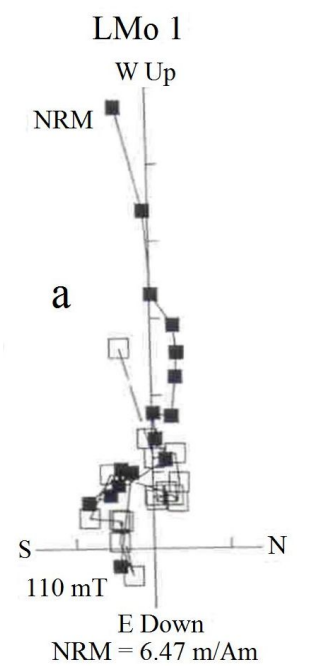

LMo 8

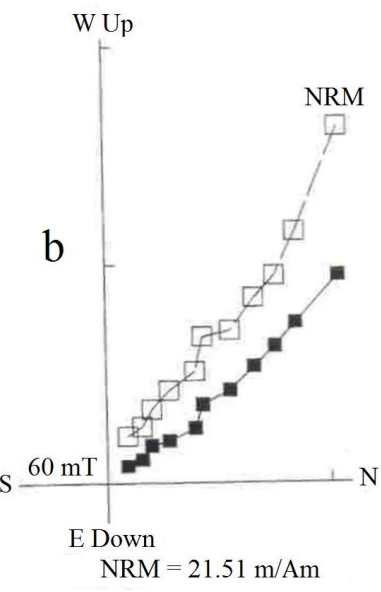

LMo 9

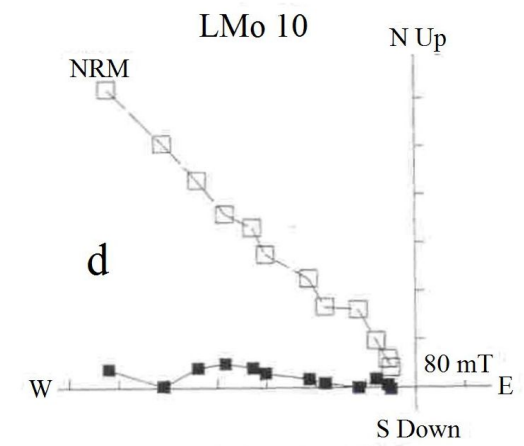

$\mathrm{NRM}=8.80 \mathrm{~m} / \mathrm{Am}$

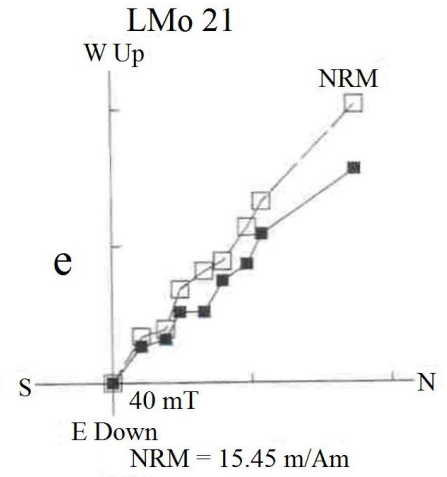

Figure 7. Vector components diagrams showing the behavior of typical samples from LMo site.

\section{CS5}

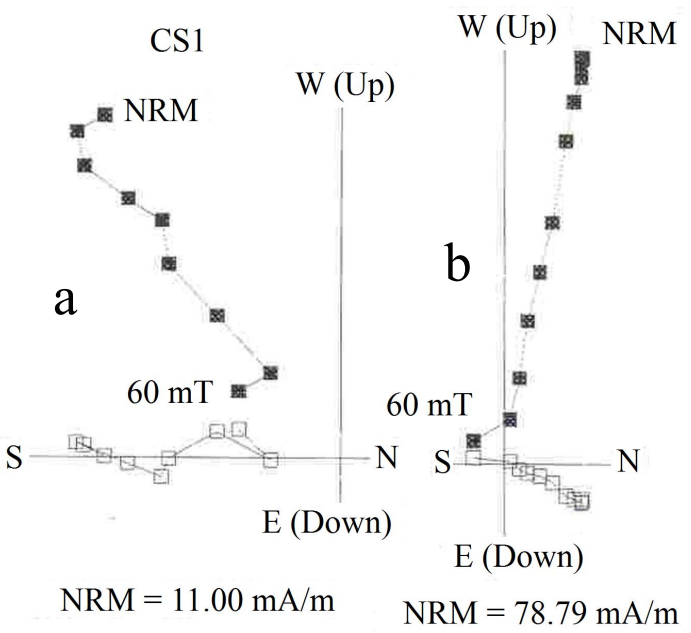

Figure 8. Examples of Zijderveld diagrams for CS site.

As depicted in Table 1, in general MAD values were very low. The number and intervals of demagnetization steps to isolate the ChRM and VGPs positions are described in Table 2. Except LS1, the sections shows normal and intermediate 
Table 1. Range and percentage of MAD values discriminate by sites.

\begin{tabular}{cccc}
\hline Site & $0^{\circ}-5^{\circ}(\%)$ & $5.1^{\circ}-10^{\circ}(\%)$ & $10.1^{\circ}-15^{\circ}(\%)$ \\
\hline SB2 & - & 50.0 & 50.0 \\
PR2 & 69.23 & 30.77 & - \\
LS1 & 30.77 & 46.15 & 23.08 \\
CM & 66.7 & 33.3 & - \\
LMo & 21.74 & 65.22 & 13.04 \\
CS & 25.0 & 75.0 & - \\
\hline
\end{tabular}

Table 2. Values of characteristic remanent magnetization, virtual geomagnetic pole positions, and intervals of selected ChRM for each sample. Negatives values show negative inclination or VGP located in the Southern Hemisphere. Intervals of selected ChRM are given in $\mathrm{mT}$. References: D: Declination, I: Inclination, Long.: Longitude, Lat.: Latitude, IChRM: Intervals of selected ChRM, Or.: Origin in the Zijderveld diagram.

\begin{tabular}{|c|c|c|c|c|c|c|c|c|c|c|c|}
\hline Sample & $\mathrm{D}^{\circ}$ & $\mathrm{I}^{\circ}$ & Long. E & Lat. & Int. ChRM & Sample & $\mathrm{D}^{\circ}$ & $\mathrm{I}^{\circ}$ & Long. E & Lat. & Int. ChRM \\
\hline \multicolumn{6}{|c|}{ SB2 } & 33 & 45 & -13 & 360 & 37 & 0 - Or. \\
\hline 1 & 5 & -36 & 311 & 69 & $12-60$ & 34 & 38 & -5 & 350 & 39 & 9 - Or. \\
\hline 2 & 15 & -44 & 343 & 71 & $6-25$ & 35 & 31 & -35 & 358 & 56 & 9 - Or. \\
\hline 3 & 8 & -2 & 310 & 50 & $25-60$ & 36 & 45 & 16 & 348 & 26 & $0-15$ \\
\hline 4 & 12 & -49 & 345 & 76 & $0-90$ & 37 & 62 & 47 & 349 & 0 & $0-20$ \\
\hline 5 & 25 & 1 & 333 & 43 & $30-60$ & 38 & 41 & -7 & 353 & 38 & $0-20$ \\
\hline 6 & 20 & -35 & 343 & 63 & 6 - Or. & 39 & 41 & -12 & 356 & 40 & 0 - Or. \\
\hline 7 & 350 & -28 & 276 & 63 & $9-40$ & & & & LS1 & & \\
\hline 8 & 1 & -33 & 300 & 68 & 0 - Or. & 1 & 147 & 31 & 58 & -53 & 0 - Or. \\
\hline 9 & 53 & -24 & 13 & 36 & $3-25$ & 2 & 175 & 30 & 106 & -65 & $12-30$ \\
\hline 10 & 40 & -7 & 353 & 39 & 12 - Or. & 3 & 62 & 70 & 331 & -18 & $0-25$ \\
\hline 12 & 22 & -50 & 7 & 70 & $3-25$ & 5 & 160 & 51 & 50 & -72 & $0-50$ \\
\hline 13 & 359 & -29 & 296 & 65 & $12-40$ & 6 & 177 & 9 & 112 & -54 & $6-25$ \\
\hline 14 & 8 & -23 & 314 & 61 & $15-50$ & 7 & 229 & 70 & 247 & -55 & $3-20$ \\
\hline 15 & 333 & -58 & 204 & 69 & $15-60$ & 8 & 183 & 19 & 123 & -59 & $3-60$ \\
\hline 16 & 25 & -37 & 352 & 60 & $6-50$ & 9 & 192 & 30 & 144 & -63 & $3-40$ \\
\hline 17 & 15 & -37 & 335 & 67 & $12-50$ & 11 & 281 & 80 & 274 & -34 & $3-15$ \\
\hline 18 & 2 & -30 & 303 & 66 & $12-40$ & 12 & 184 & 28 & 126 & -64 & 3 - Or. \\
\hline 19 & 22 & -41 & 352 & 65 & $9-40$ & 13 & 199 & 75 & 275 & -66 & $3-30$ \\
\hline 20 & 334 & -54 & 216 & 69 & $0-80$ & 14 & 142 & 27 & 55 & -48 & 0 - Or. \\
\hline 21 & 1 & -46 & 302 & 67 & 6 - Or. & 15 & 149 & 18 & 68 & -48 & $0-30$ \\
\hline 22 & 69 & -70 & 69 & 43 & $3-20$ & & & & LMo & & \\
\hline 23 & 173 & -58 & 110 & -10 & $20-50$ & 1 & 261 & -25 & 185 & 5 & $0-25$ \\
\hline 24 & 69 & -25 & 25 & 24 & 40 - Or. & 2 & 284 & 2 & 212 & 8 & $6-20$ \\
\hline 25 & 351 & 33 & 288 & 31 & $3-12$ & 3 & 305 & -36 & 216 & 37 & $0-6$ \\
\hline
\end{tabular}




\section{Continued}

\begin{tabular}{|c|c|c|c|c|c|c|c|c|c|c|c|}
\hline 26 & 287 & 76 & 268 & -29 & $15-60$ & 4 & 278 & -35 & 194 & 20 & $0-40$ \\
\hline 27 & 7 & -33 & 315 & 67 & 3 - Or. & 5 & 298 & -59 & 191 & 47 & $0-25$ \\
\hline 30 & 69 & -76 & 82 & 45 & $9-30$ & 6 & 304 & -36 & 215 & 36 & 0 - Or. \\
\hline 31 & 73 & -58 & 52 & 35 & $3-25$ & 7 & 308 & -33 & 220 & 37 & $0-25$ \\
\hline 34 & 142 & -77 & 326 & -57 & 3 - Or. & 8 & 318 & -46 & 222 & 50 & 0 - Or. \\
\hline \multirow[t]{2}{*}{36} & 91 & -50 & 53 & 19 & $3-30$ & 9 & 244 & -57 & 158 & 15 & 0 - Or. \\
\hline & & & PR2 & & & 10 & 274 & -44 & 187 & 22 & 0 - Or. \\
\hline 1 & 40 & -2 & 351 & 36 & 0 - Or. & 11 & 298 & -48 & 202 & 39 & $0-60$ \\
\hline 2 & 33 & 9 & 340 & 36 & 0 - Or. & 12 & 304 & -56 & 199 & 48 & $0-50$ \\
\hline 3 & 31 & 4 & 339 & 39 & 0 - Or. & 13 & 289 & -40 & 200 & 29 & 0 - Or. \\
\hline 4 & 49 & 3 & 357 & 29 & 0 - Or. & 14 & 295 & -54 & 194 & 41 & $0-40$ \\
\hline 5 & 41 & -14 & 356 & 41 & 0 - Or. & 15 & 316 & -59 & 204 & 58 & $0-25$ \\
\hline 6 & 40 & 8 & 347 & 32 & 0 - Or. & 16 & 344 & -36 & 263 & 56 & $3-25$ \\
\hline 7 & 38 & 8 & 345 & 33 & $0-25$ & 17 & 222 & -15 & 156 & -21 & $25-80$ \\
\hline 8 & 45 & 11 & 351 & 28 & 0 - Or. & 18 & 347 & -33 & 267 & 65 & $6-25$ \\
\hline 9 & 52 & -3 & 181 & 29 & 0 - Or. & 19 & 19 & -74 & 67 & 76 & $0-40$ \\
\hline 10 & 10 & -35 & 323 & 67 & 0 - Or. & 20 & 355 & -44 & 280 & 64 & 9 - Or. \\
\hline 11 & 41 & 15 & 346 & 29 & 0 - Or. & 21 & 318 & -41 & 227 & 48 & 0 - Or. \\
\hline 12 & 37 & 19 & 340 & 29 & 0 - Or. & 22 & 317 & -67 & 187 & 63 & 0 - Or. \\
\hline 13 & 37 & 0 & 347 & 37 & 0 - Or. & 23 & 322 & -69 & 183 & 67 & 12 - Or. \\
\hline 14 & 44 & 8 & 351 & 30 & 0 - Or. & & & & CM1 & & \\
\hline 15 & 49 & 11 & 354 & 26 & 0 - Or. & 1 & 37 & -15 & 339 & 37 & 12 - Or. \\
\hline 16 & 32 & 14 & 337 & 34 & $0-15$ & 2 & 4 & -40 & 298 & 61 & 0 - Or. \\
\hline 17 & 12 & -51 & 348 & 77 & 12 - Or. & 3 & 313 & -66 & 188 & 60 & 30 - Or. \\
\hline 18 & 145 & -53 & 8 & 59 & 6 - Or. & 4 & 307 & -31 & 220 & 36 & $3-40$ \\
\hline 19 & 50 & -14 & 5 & 34 & $0-40$ & 5 & 334 & -6 & 257 & 37 & 4 - Or. \\
\hline 20 & 32 & -44 & 60 & 8 & 15 - Or. & 6 & 8 & 1 & 301 & 37 & $3-100$ \\
\hline 21 & 354 & -36 & 282 & 69 & $12-30$ & & & & CM2 & & \\
\hline 22 & 49 & -6 & 320 & 32 & 0 - Or. & 1 & 3 & -20 & 295 & 49 & 0 - Or. \\
\hline 23 & 29 & -6 & 340 & 44 & 0 - Or. & 2 & 331 & -70 & 181 & 72 & 3 - Or. \\
\hline 24 & 201 & -25 & 142 & -33 & $18-60$ & 3 & 44 & -24 & 349 & 37 & 9 - Or. \\
\hline 25 & 48 & -8 & 180 & 33 & $0-30$ & 4 & 47 & 7 & 343 & 22 & 60 - Or. \\
\hline 26 & 59 & -73 & 74 & 50 & $9-25$ & 5 & 15 & -6 & 310 & 40 & 40 - Or. \\
\hline 27 & 2 & -77 & 116 & 66 & $10-40$ & 6 & 324 & -45 & 229 & 53 & 40 - Or. \\
\hline 28 & 345 & -72 & 144 & 71 & 12 - Or. & & & & $\mathrm{CS}$ & & \\
\hline 29 & 38 & -8 & 351 & 40 & $0-60$ & 1 & 230 & 1 & 167 & -24 & $3-25$ \\
\hline 30 & 56 & -3 & 5 & 26 & 0 - Or. & 3 & 21 & 18 & 313 & 27 & $6-50$ \\
\hline 31 & 35 & -40 & 7 & 56 & 12 - Or. & 5 & 283 & 6 & 212 & 6 & 3 - Or. \\
\hline 32 & 47 & -16 & 3 & 37 & 0 - Or. & 6 & 354 & 71 & 286 & -17 & $3-30$ \\
\hline
\end{tabular}


polarity directions far from the present GF, while reversed polarities were recorded at SB2, PR2 and LS1. Figure 9 illustrates the stereographic projection of ChRM isolated from the sites under study. Figures 10-12 summarize the changes in the declinations and inclinations of the ChRM for the sections reported here.

The declination and inclination profiles from SB2 shows an important correlative shift toward higher negative values in inclination of $\sim 40^{\circ}-50^{\circ}$ between samples 1 and 16 in the upper portion of the section; also shows wide pulses with reverse directions and transitional positions between samples SB2 20 and SB2 30 (Figure 10). The more conspicuous long declination and inclination departures from SB2 are depicted between dashed lines and indicated with arrows. SB2 records suggest a shift from to intermediate and reversed positions during the early and middle Holocene (9 - 5 ky BP). As illustrated in Figure 11, a similar fact is also observed in the PR2 log that shows positive inclination values in the upper portion until sample PR2 16 with a shift to higher negative values between samples PR2 17 and PR2 35. The more notably fluctuations in declination occurs between samples PR2 18 and PR2 28. The stereoplots depicted in Figure 9 shows that the totality of the samples horizontally taken at LS1 recorded reverse magnetization directions dated at $\sim 5.3 \mathrm{ky}$ BP during the middle Holocene.

In LMo a significant but gently westward shift in declination (over $90^{\circ}$ ) and less conspicuous shallowing of the inclination can be observed (Figure 12(a)).

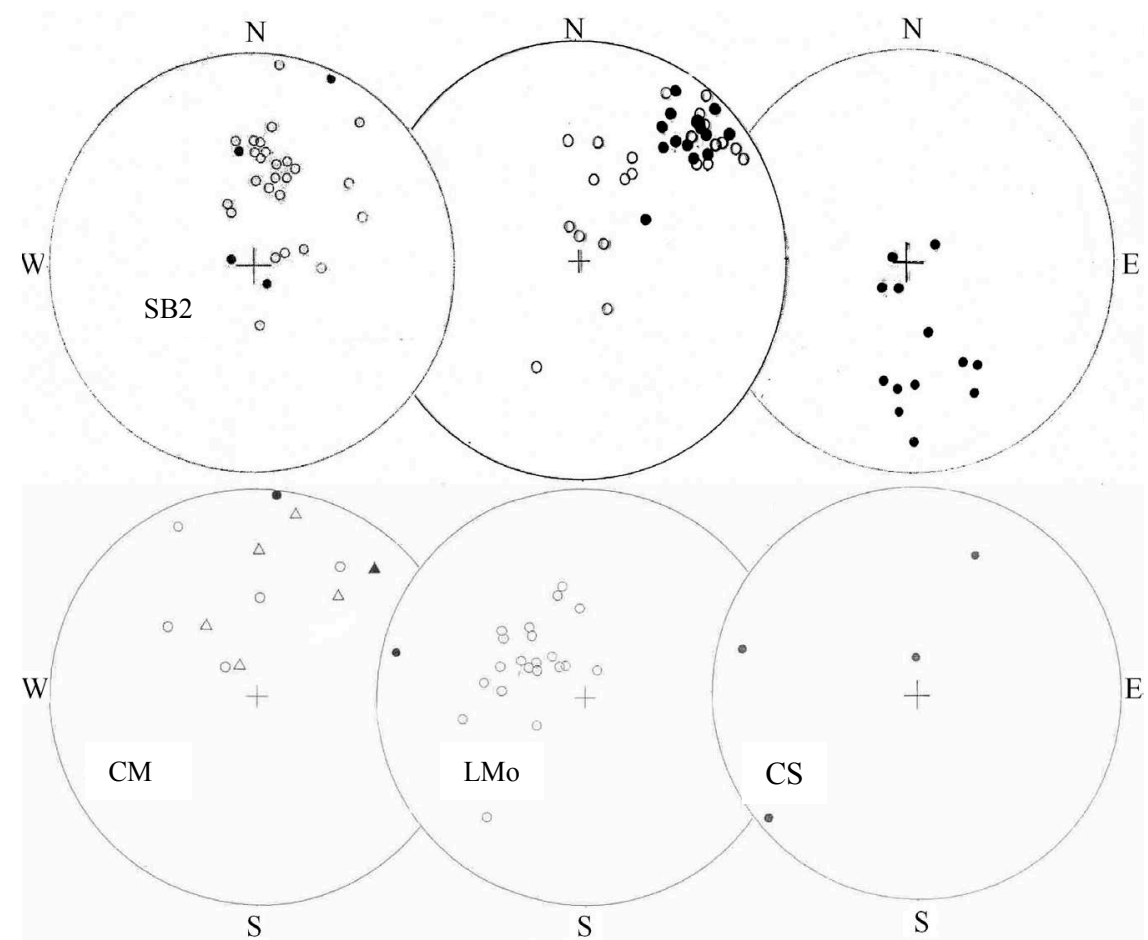

Figure 9. Directional data with field correction of characteristic remanent magnetizations (ChRM) of each sample for the section reported in this paper. Negative inclination (open circle), and positive inclination (solid circle). The triangles in Figure 9, Figure 13 and Figure 14 represent CM2. 


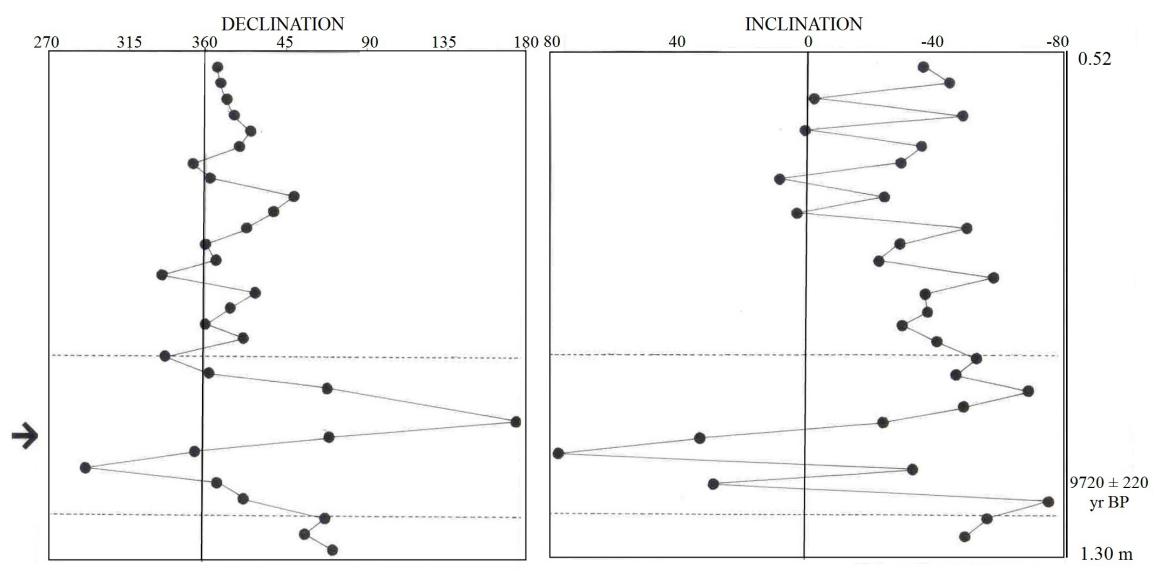

Figure 10. Magnetograms showing the stratigraphic presentation of declination and inclination profile from SB2. The more conspicuous long directions departures are depicted between dashed lines and pointed with an arrow.

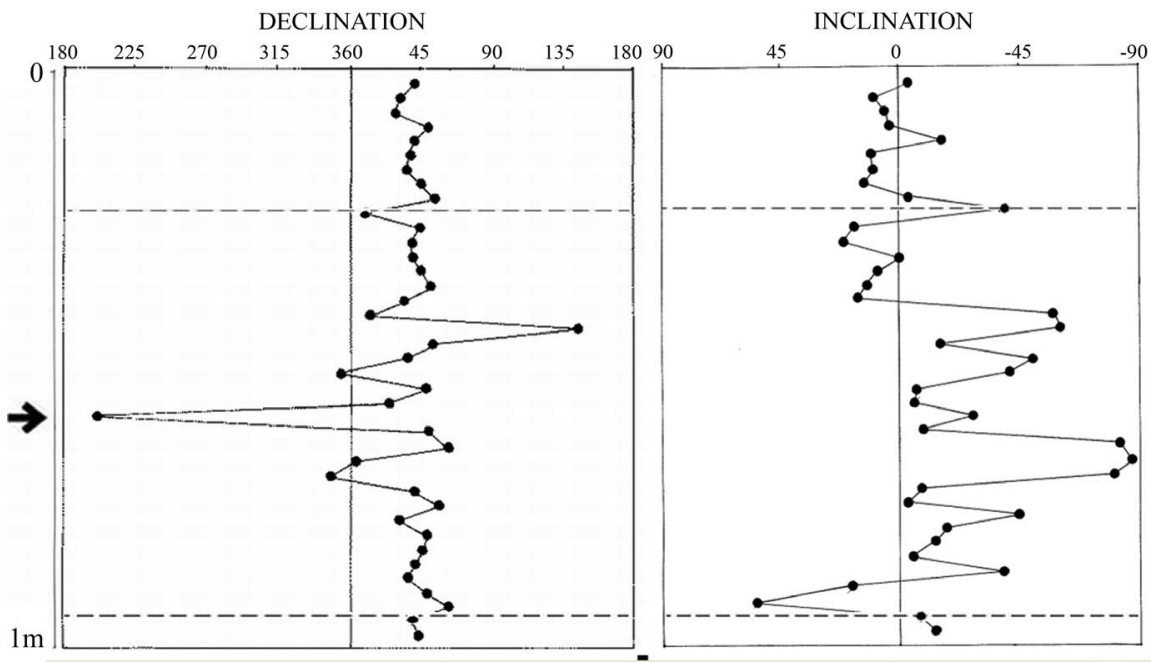

Figure 11. Declination and inclination logs from PR2 site.

Both samplings in CM recorded negative to positive changes in inclination with similar directions during the first millennium bp (Figure 12(b)). Despite that scarce number of cores from CS, they exhibit intermediate and reverse directions, a fact also observed in other sites from southern Patagonia in Argentina and Chile (see below).

Figure 13 depicts the virtual geomagnetic pole positions (VGP) calculated from the directions of Table 2. When plotted on a present world map, they show intermediate VGPs from the rotation axis of the Earth in the northern Hemisphere between $60^{\circ}$ and $30^{\circ}$ (mainly in North Africa) and reverse VGPs located in the southern Hemisphere (Figure 14). Particularly, the PR2 VGPs coincides with the ones calculated for PA11 and Las Buitreras sites, respectively located in NW and SE Patagonia (Nami, 1999b). The geographical distribution defined from spherical statistical analysis suggests that not only the transitional VGPs have peculiar distributions, but VGPs corresponding to stable polarity fields 


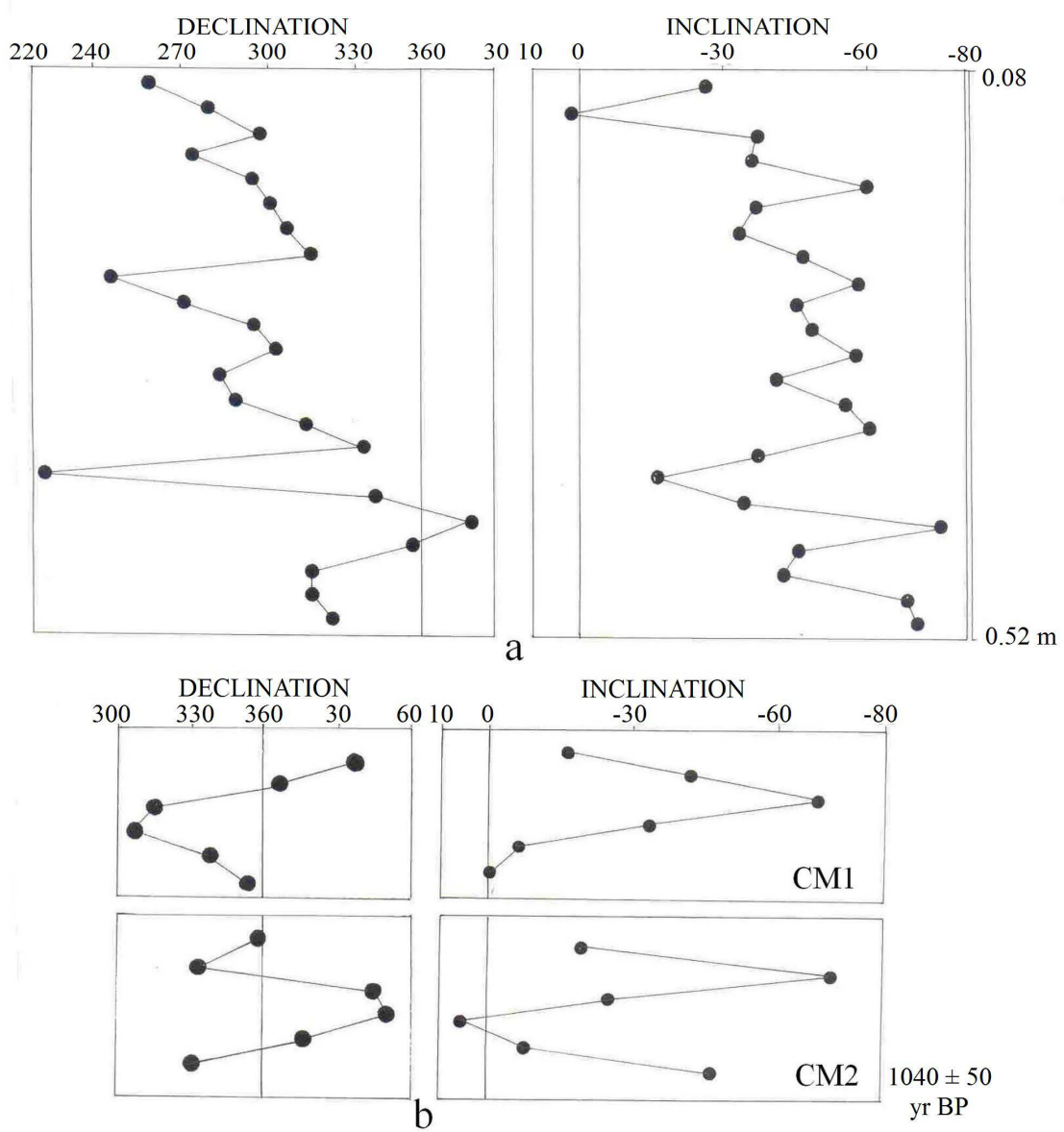

Figure 12. Declination and inclination logs according to their stratigraphic presentation from LM (a) and CMo (b).

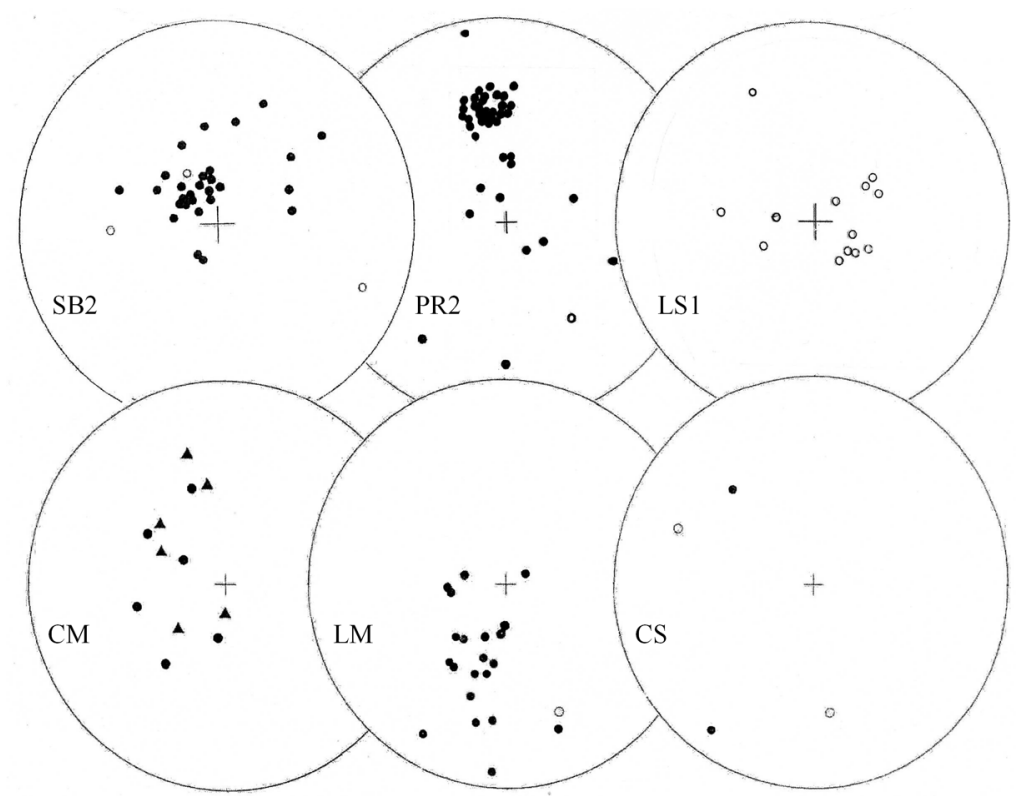

Figure 13. Stereographic projection of VGP calculated from directions of ChRM isolated in the sites mentioned in the text. Solid circles show those ones located in the Northern Hemisphere. The center of the projection is the Geographic Southern Pole. 

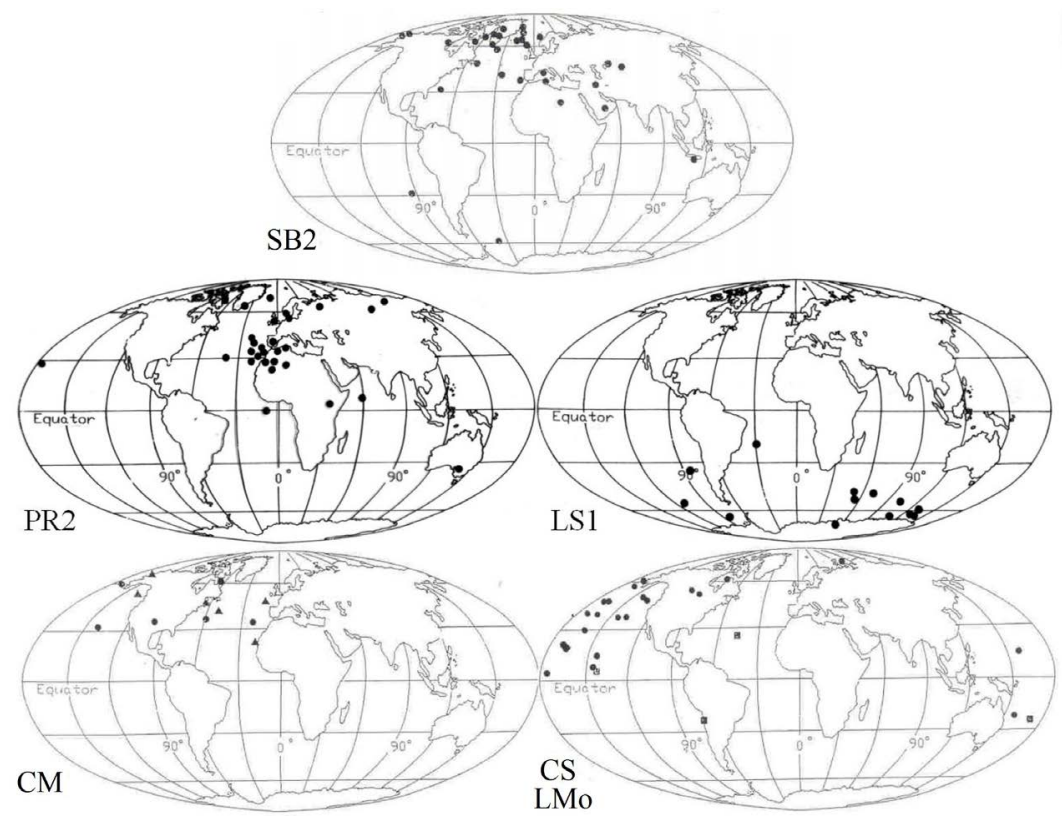

Figure 14. World map showing the location of the VGP obtained from the sites described in Table 2.

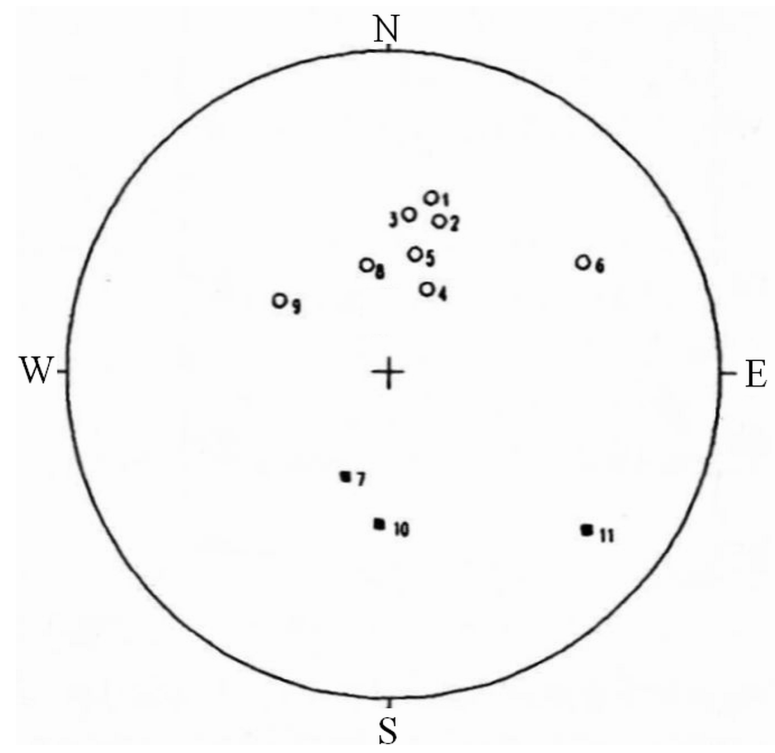

Figure 15. Stereographic projection of the Angostura Blanca directions. Open and solid circles respectively show negative and positive inclination (After Sinito et al., 1997; Figure $4(\mathrm{~b}))$.

or to excursional fields seem to follow a geographical pattern that shows a non uniform distribution in longitude (Mena \& Nami, 2002; Nami \& Mena, 2010), those ones in the southern hemisphere are located in South America, South Africa, Australasia and Antarctica. These positions agree remarkably well with VGPs observed in previous paleomagnetic studies performed on Latest Pleistocene and Holocene sections from the southern cone of South America (Nami, 1999a, 2006, 2008, 2011, 2012; Nami et al., 2017). Remarkably is that this dis- 
tribution shows strong similarities with the VGPs calculated for the Laschamp and Iceland basin excursions respectively dated at $\sim 40 \mathrm{ky}$ and $\sim 180-220 \mathrm{ky}$ BP interval (Laj \& Channell, 2007). Is also remarkably, the agreement of VGPs located in southern Africa with the VGPs calculated for the Late Pleistocene excursion identified in several parts of Argentina and dated at $\sim 26-30 \mathrm{ky}$ BP (Orgeira et al., 1990, 1996; Vizán \& Azcuy, 2010). Besides, the location of transitional VGPs in Africa and Australasia were observed in several records from different periods of the Earth history (e.g., Coe \& Glen, 2004; Creer \& Ispir, 1970; Gurarii, 2005; Herrero-Bervera \& Coe, 1999; Hoffman \& Singer, 2004; Ohno et al., 2008).

\section{Discussion}

In conclusions of the investigations described above, new data obtained at sediments from various environments and lithologies cored in northern and southern Patagonia have been found to contain records of anomalous GF behavior during the Holocene. Actually, besides normal and intermediate polarity directions far from the present GF, most of the sections reported here shows reversed polarities. They were recorded at SB2, LS1 and PR2 sites in San Blas Bay as well Saenz cave in the Pali Aike area, showing similar directions observed in nearby sites from southern Patagonia in Argentina and Chile. In fact, previous results obtained at several sections produced diverse samplings, stable and instable records with normal, intermediate and reverse directions happening at different times during the last $\sim 11-10 \mathrm{ky}$. A brief summary follows. Early in 1990, the Angostura Blanca rockshelter, Chubut province in central Patagonia, yielded reverse directions at $\sim 2 \mathrm{ky} \mathrm{BP}$ (Figure 15). At Piedra del Aguila 11 rockshelter (Neuquén province) in Northwestern Patagonia, a multicomponent sample showed that despite unreliable to isolated directions, the vector changes from negative to positive inclinations (intermediate or reverse) moving in a great circle at $\sim 2$ ky BP (Figure 16). In southern Chilean Patagonia, Mylodon cave (Na$\mathrm{mi}, 1995 \mathrm{a}$ ), yielded a stable record with reverse directions between 10 and $\leq 5 \mathrm{ky}$ BP (Figure 17(b), Figure17(c)). There, clear reverse samples were dated during the middle Holocene at $\sim 5.5$ ky BP (Figure 17(d), Figure 17(e)); nearby, Cueva del Medio yielded a record from a section dated at $\sim 10.0$ ky BP with samples that recorded two magnetic components with normal and intermediate directions (Figure 18) indicating the presence of an anomalous GF behaviour after deposition (Nami \& Sinito, 1995). At about $135 \mathrm{~km}$ east in southern Argentina, Las Buitreras cave yielded an unstable record with normal, intermediate and reverse directions dated at $\sim 4.3 \geq 10 \mathrm{ky}$ BP (Figure 19; Nami, 1999a). Highly reliable samples taken at Don Ariel cave (Nami, 1994) also yielded remanence directions corresponding to intermediate and reversed magnetization directions during the early and middle Holocene (Figure 20). These records along with the ones presented in this paper strengthen the hypothesis of the existence of the Mylodon excursion in southern Patagonia. On the other hand, the presence of intermediate 


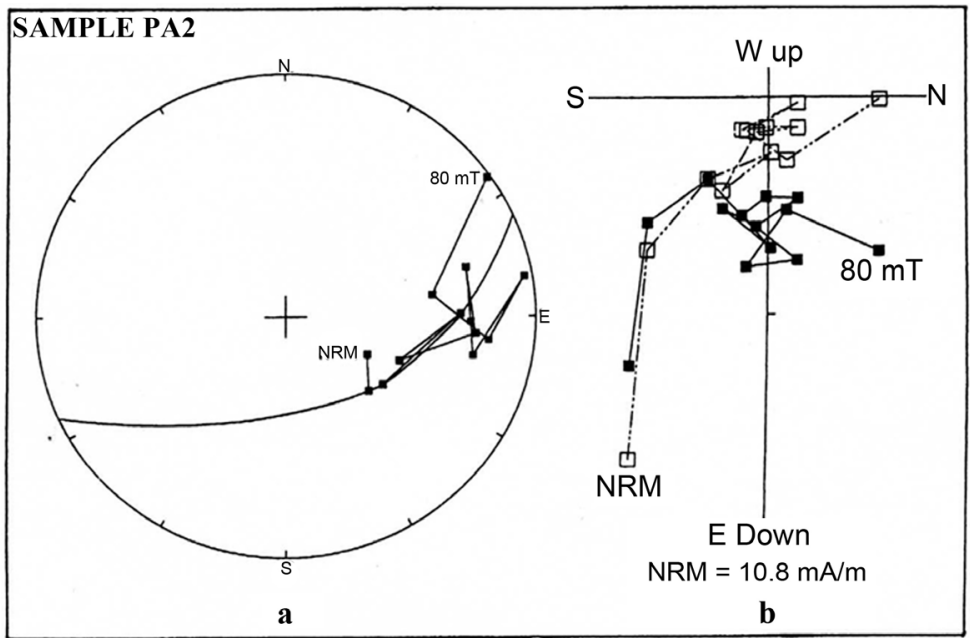

Figure 16. Multicomponent sample from Piedra del Aguila 11 site (\#2) from NW Patagonia that despite unreliable to isolate directions shows that the vector changes from negative to positive inclinations (intermediate or reverse) moving in a great circle. (a) Stereographic projection; (b) Zijderveld diagram (After Nami, 1999a; Figure 7).

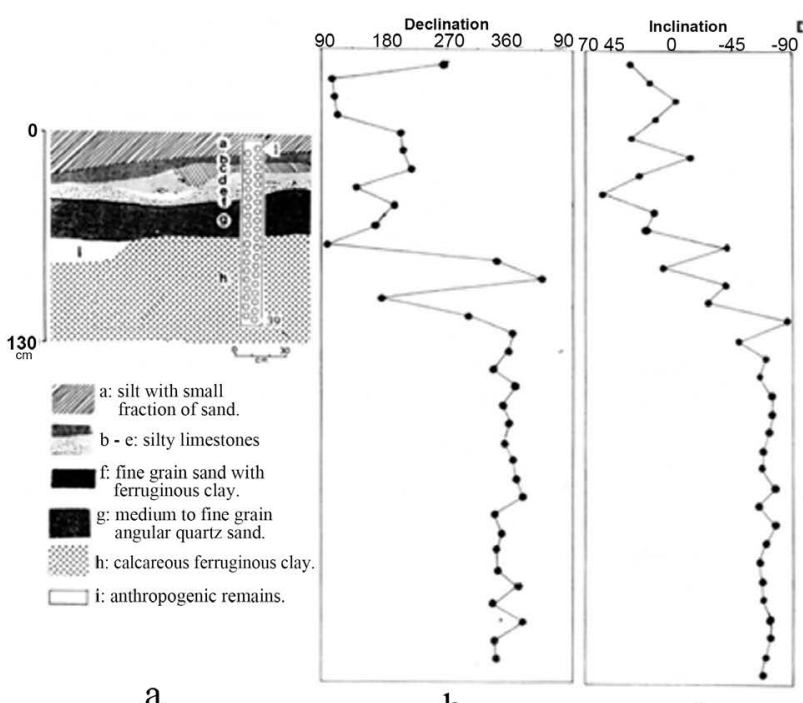

b

C
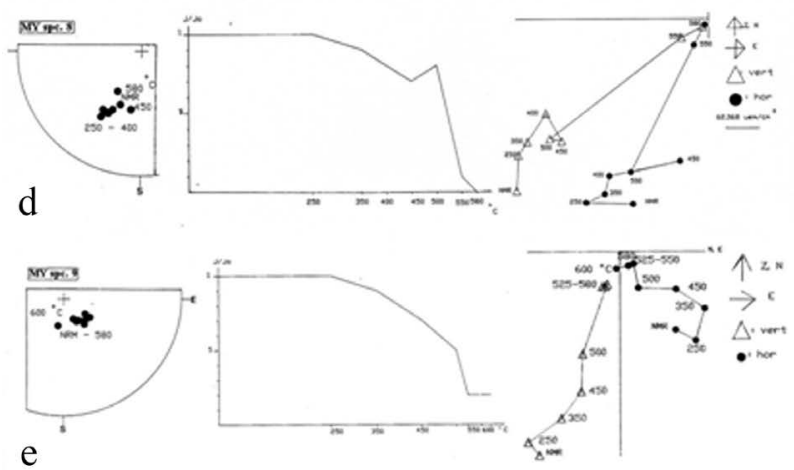

Figure 17. Different details of the Mylodon cave paleomagnetic sampling. (a) Stratigraphic section and sampling location; (b, c) Declination and Inclination logs; (d, e) Examples of reverse samples showing its stereoplot, demagnetization curves using thermal cleaning and Zijderveld diagrams (modified after Nami, 1995a). 

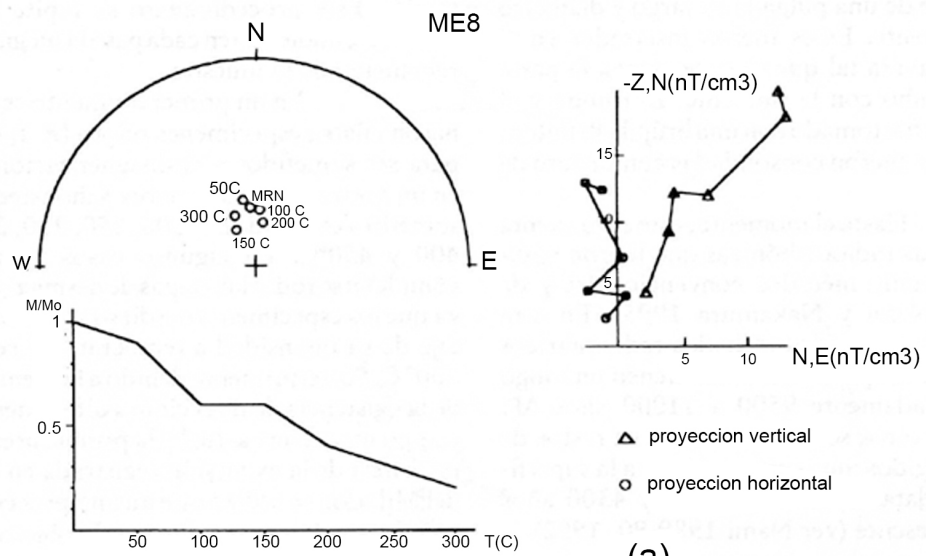

\begin{abstract}
$\Delta$ proyeccion vertical
o proyeccion horizontal
\end{abstract}

(a)
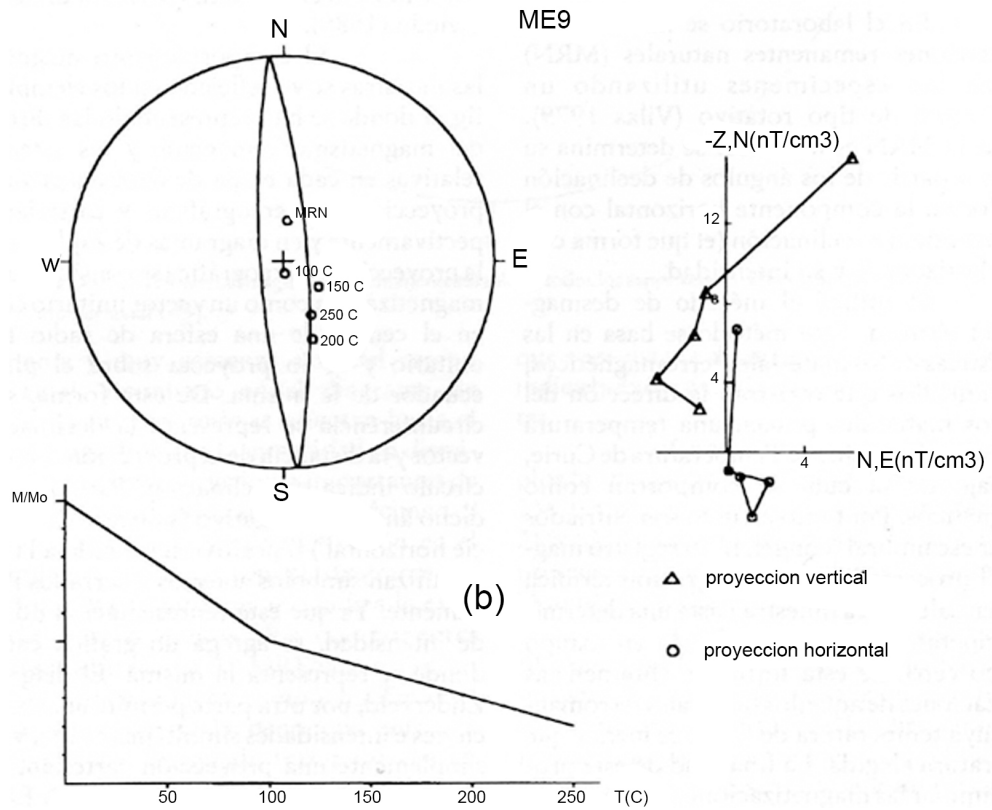

$\Delta$ proyeccion vertical

- proyeccion horizontal

Figure18. Examples of samples from Cueva del Medio with normal and oblique directions. The maximum circle indicates at least two at least two overlapped directions (After Nami \& Sinito, 1995: Figure 3).

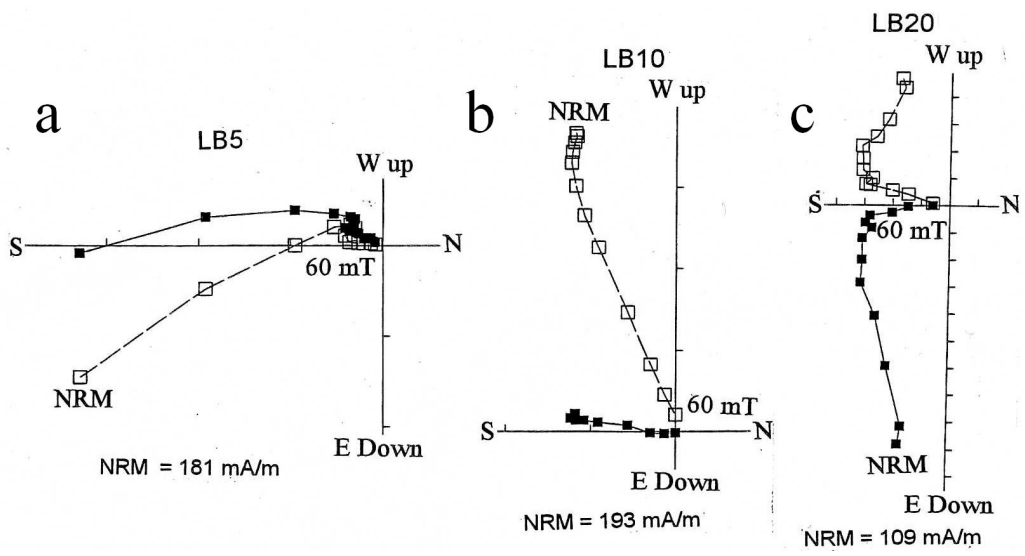

Figure 19. Examples of Zijderveld diagrams with southward directions from Las Buitreras cave (modified after Nami, 1999a, Figure 6). 

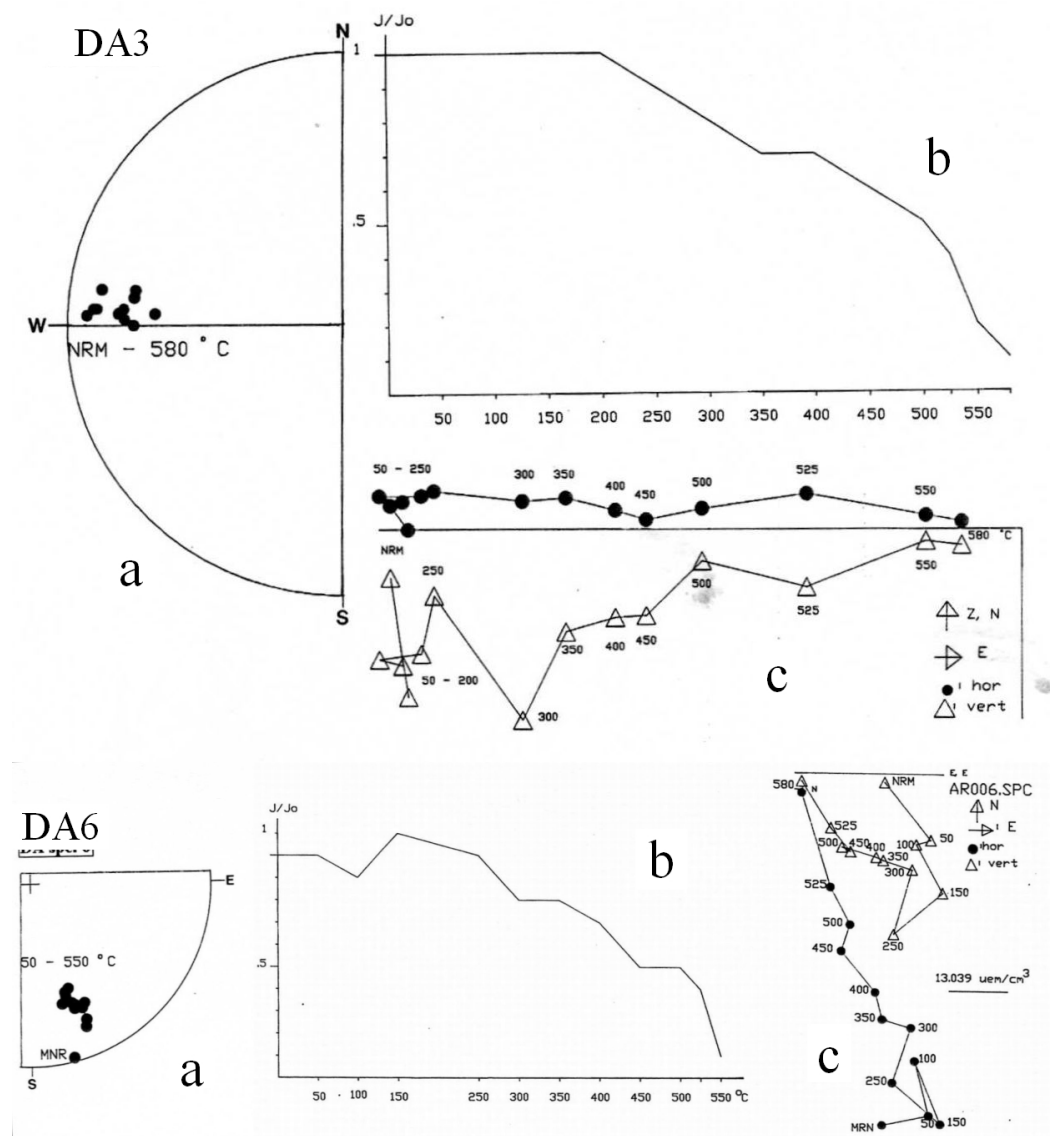

Figure 20. Examples of reverse samples (DA3 and DA6) dated at $2590 \pm 50$ (Beta-54775) and $2760 \pm 80$ (Beta-54774) years BP from Don Ariel cave. (a) Stereographic projection; (b) Demagnetization curves using thermal cleaning; (c) Zijderveld diagram (modified after Nami, 1994).

and reverse VGPs in San Blas records and other sites also supports its regional extent in the southern cone of South America with evidence records in Northeastern Patagonia. In the particular case presented in the previous sections, SB2, PR2, and mainly LS1 yielded new light to date with precision one of the largest amplitude GF fluctuations with reverse directions that happened during the Middle Holocene showing that one of the peaks of these oscillations occurred at $\sim 5.3 \mathrm{ky}$ BP. This situation strengthens the hypothesis of the real existence of anomalous GF behavior during the Holocene in southern Patagonia (Nami, 1994, 1995a, 1999a, 2012; Nami \& Sinito, 1995).

As previously was noted by Nami (2012), in some areas of the southern cone of South America, during at least the last $\sim 11-10 \mathrm{ky} \mathrm{BP,} \mathrm{the} \mathrm{GF} \mathrm{might} \mathrm{have}$ been undergoing an anomalous behavior with large amplitude fluctuations, occasionally reaching reverse polarity positions, more than once. If correctly represent the GF record, they are revealing that these kinds of directions might haen in a very short time span, probably decades or centuries; mainly during the terminal Pleistocene and early Holocene ( 11 - 9/7 ky BP), middle ( 5 - 4 ky $\mathrm{BP})$ and late ( 2.5 - 2.0 ky BP) Holocene. Also, very low negative and positive 
inclination values occurred in the last millennia and centuries (i.e. LM and CS; Nami, 2006, 2012). These kind of anomalous records were also observed in several parts of the Earth (Burakow \& Nachasova, 1990; Clark \& Kennett, 1973; Dergachev et al., 2004; Guskova et al., 2008; Kochegura \& Pisarevsky, 1994; Lund et al., 2007, 2008; Nami, 1999c, 2012, 2015; Nami et al. 2016, 2019; Noël, 1975, 1977; Noël \& Tarling, 1975; Pospelova, 1981, 1990; Ransom, 1973; Raspopov et al., 2003; Urrutia Fucugauchi et al., 1995; Ortega-Guerrero \& Urrutia Fucugauchi, 1997; Vitorello \& Van der Voo, 1977; Woolin et al., 1971; Zhu et al., 1998; Wiegank et al., 1990). Hence, the hypothesis of the global excursional state of the Holocene GF with not coetaneous intermediate and reverse directions was proposed (Nami, 1999c). The records informed in this paper, suort this idea. Besides, LS1 shed new light about the chronological position of one of the largest amplitude fluctuations that occurred in SE Buenos Aires province in eastern part of Northern Patagonia which agrees with other records with reverse directions across the world.

During the last $780 \mathrm{ky} \mathrm{BP}$, the Brunhes Chron showed that the GF polarity has been "normal" as it is now. However, there have been a number of occasions when the GF either briefly reverse or behaves anomalously. In other words, this normal polarity has been interrupted by significant departures from the dipole field configuration (Lund et al., 2001; Petrova \& Pospelova, 1990; Tarling, 1983; Thouveny \& Creer, 1992). These kinds of departures are considerably larger than those seen in secular variations observed during historical times, and sometimes even attain oosite polarity, originating GF excursions. They are short intervals of anomalous field directions that occur within a broader interval of "stable" normal or reversed magnetic polarity. While certain excursions may have regional or continental scale; other ones show a global existence (Bogue \& Merril, 1992; Merrill \& McFadden, 1994; Laj \& Channell, 2007; Roberts, 2008). During the Middle Holocene several anomalous records with intermediate and reverse VGPs were registered at different materials, times and places across de world. In the Northern Hemisphere, reliable records obtained in lava flows from central Mexico dated by $14 \mathrm{C}$ at $4070 \pm 150$ and $4700 \pm 200$ uncalibrated years bp show a strong eastward swing in declination (González et al., 1997). Similar swings with wide amplitude variations in declination and inclination were observed in lake sediments of the Valley of Mexico during the same time span (Ortega-Guerrero \& Urrutia-Fucugauchi, 1997; Urrutia-Fucugauchi et al., 1995). Chalco lake lacustrine declination record shows a pronounced swing at $\sim 5 \mathrm{ky}$ BP. Also, the Red Rock site in California (USA) yielded intermediate and reverse polarity positions also at $\sim 5 \mathrm{ky} \mathrm{BP}$ (Nami, 1999c). In Asia, Chinese fresh-water sediments from Beijing yielded an excursion occurring between 5060 and $4860 \pm$ 90 years BP (Zhu et al., 1998) and besides, several cores from the Barents sea sediments yielded records of the Solovki excursion dated at $4.5-7.5 \mathrm{ky}$ BP (Guskova et al., 2008). As previously described, the Southern Cone of South America 22 sections (12 located in Patagonia), showed anomalous intermediate 
Table 3. Summary of number of sites, location, number and range of ${ }^{14} \mathrm{C}$ dates of sampled deposits, number, quality and polarity of the samples. References: ND: number of ${ }^{14} \mathrm{C}$ dates in the sites, ${ }^{*}$ : indicate indirect dates, $\mathrm{N}$ : number of samples used in the analysis, $\mathrm{P}$ : polarity of the core, $\mathrm{N}$ : normal, I: Intermediate, R: reverse. HRe: highly reliable, MRe: moderately reliable, PRe: poorly reliable (Nami, 1999a, 2012).

\begin{tabular}{|c|c|c|c|c|c|c|}
\hline Site & Coordinates & $\begin{array}{c}\text { Age } \\
(\mathrm{ky} \mathrm{BP})\end{array}$ & ND & $\mathrm{P}$ & $\mathrm{N}$ & SQ \\
\hline $\begin{array}{c}\text { Alero de las } \\
\text { Circunferencias }\end{array}$ & $22^{\circ} 56^{\prime} \mathrm{S} 65^{\circ} 21^{\prime} \mathrm{W}$ & $\sim 10.7-7.9$ & 5 & N-I & 36 & HRe-MRe \\
\hline Puerto Segundo & $25^{\circ} 59.03^{\prime} \mathrm{S} 54^{\circ} 39.74^{\prime} \mathrm{W}$ & $\sim 7-0.6$ & * & $\mathrm{I}-\mathrm{R}$ & 50 & HRe \\
\hline Aserradero & $26^{\circ} \mathrm{S} 54^{\circ} 36.44^{\prime} \mathrm{W}$ & $\sim 7-1$ & * & N-I-R & 20 & HRe-MRe \\
\hline Arroyo Yarará & $26^{\circ} \mathrm{S} 55^{\circ} \mathrm{W}$ & $\sim 7-1$ & * & N-I & 14 & HRe-MRe \\
\hline Barranca Pelada & $30^{\circ} 15^{\prime} \mathrm{S} 57^{\circ} 37^{\prime} \mathrm{W}$ & $\sim 3.2-0.3$ & * & N-I & 34 & HRe-MRe \\
\hline San Juan & $30^{\circ} \mathrm{S} 57^{\circ} 44^{\prime} \mathrm{W}$ & $\geq 3.0$ & * & N-I & 21 & HRe-MRe \\
\hline Santa Lucía & $30^{\circ} 15.7^{\prime} \mathrm{S} 57^{\circ} 37.30^{\prime} \mathrm{W}$ & $\sim 11-0.2$ & 1 & N-I & 74 & HRe-MRe \\
\hline Barranca de Maipú & $33^{\circ} 7^{\prime} 36 \mathrm{~S} 68^{\circ} 41^{\prime} 29 \mathrm{~W}$ & $\sim 9.7$ & 1 & I & 47 & $\mathrm{HRe}$ \\
\hline Lomas del Mirador & $34^{\circ} 39.29^{\prime} \mathrm{S} 58^{\circ} 32.17 \mathrm{~W}$ & $\sim 10-0.05$ & 14 & N-I & 149 & HRe-MRe \\
\hline Urupez & $34^{\circ} 49^{\prime} 15 \mathrm{~S} 55^{\circ} 19^{\prime} 02 \mathrm{~W}$ & $\sim 10-11$ & 2 & N-I & 13 & HRe-MRe \\
\hline Piedra del Aguila 11 & $40^{\circ} 02 \_\mathrm{S}, 70^{\circ} \mathrm{W}$ & $\sim 4.9-1.9$ & 9 & N-I & 90 & HRe-MRe \\
\hline San Blas 2 & $40^{\circ} 33.39^{\prime}$ S. $62^{\circ} 14.35 \mathrm{~W}$ & $\sim 9.6-\leq 5$ & 1 & N-I-R & 30 & HRe-MRe \\
\hline Punta Rubia 2 & $40^{\circ} 46.0^{\prime} \mathrm{S}, 62^{\circ} 16.02 \mathrm{~W}$ & $\sim 10-\leq 5$ & - & N-I-R & 39 & HRe-MRe \\
\hline La Serranita 1 & $40^{\circ} 33.02^{\prime} \mathrm{S} 62^{\circ} 38.16^{\prime} \mathrm{W}$ & $\sim 5.3$ & 3 & $\mathrm{R}$ & 15 & HRe-MRe \\
\hline Angostura Blanca & $42^{\circ} 30^{\prime} \mathrm{S} 70^{\circ} \mathrm{W}$ & $\sim 2.9-2.1$ & 2 & $\mathrm{R}-\mathrm{N}$ & 11 & HRe-MRe-Pre \\
\hline Cueva del Medio & $51^{\circ} 35^{\prime} \mathrm{S} 72^{\circ} 38^{\prime} \mathrm{W}$ & $\sim 11-2.1$ & 51 & N-I & 12 & MRe-Pre \\
\hline Mylodon Cave & $51^{\circ} 35^{\prime} \mathrm{S} 72^{\circ} 38^{\prime} \mathrm{W}$ & $\sim 11-5.5$ & 31 & $\mathrm{~N}-\mathrm{R}$ & 34 & HRe \\
\hline Cueva Saenz & $51^{\circ} 44.46^{\prime} \mathrm{S} 70^{\circ} 09.92^{\prime} \mathrm{W}$ & $\leq 10$ & - & $\mathrm{I}-\mathrm{R}$ & 5 & HRe-MRe \\
\hline Las Buitreras & $51^{\circ} 45^{\prime} \mathrm{S} 70^{\circ} 10^{\prime} \mathrm{W}$ & $\geq 10-4.3$ & 2 & N-I-R & 40 & HRe-MRe \\
\hline Laguna Montecarlo & $51^{\circ} 55^{\prime} \mathrm{S}, 69^{\circ} 39^{\prime} \mathrm{W}$ & $\leq 10$ & - & N-I & 23 & HRe-MRe \\
\hline Cueva Montecarlo & $51^{\circ} 54.86^{\prime} \mathrm{S} 69^{\circ} 38.79^{\prime} \mathrm{W}$ & $\sim 1$ & 1 & N-I & 12 & HRe-MRe \\
\hline Don Ariel & $52^{\circ} \mathrm{S} 70^{\circ} 09^{\prime} \mathrm{W}$ & $\sim 7-2.6$ & 6 & $N-R$ & 15 & HRe-MRe \\
\hline
\end{tabular}

and reverse directions that remarkably agree with the above mentioned chronologies (Table 3).

\section{Conclusion}

In conclusion, paleomagnetic studies carried out at different sites belonging from diverse sedimentary environments in northern and southern Patagonia yielded normal, intermediate and reversed directions. This suggests that the Earth's magnetic field probably underwent an excursion in southern South America during the Middle Holocene. Similar events were found in different sections and materials from Eurasia, North and South America. These facts may suggest that some anomalous geomagnetic phenomena might have occurred 
globally during the more recent geological epoch; probably a global reverse excursion (Laj \& Channell, 2007; Roberts, 2008) that might have occurred in the Middle Holocene. According to Nami (2012), during about the last 11/10 ka BP, the normal polarity of the Earth's magnetic field has been interrupted by several short-lived reversed polarity events. In this scenario, the observed Middle Holocene excursion might be another short-term manifestation of this process. Finally, if the presented paleomagnetic features are true GMF behavior, the remarkably PSV record can serve to correlate regional stratigraphies, and to determine relative and absolute chronologies (e.g., Tarling, 1983; Barendrest, 1984). Besides, if the anomalous directions represent excursions (cf. Nami et al. 2016), they may be also used as dating devices (Tarling, 1983; Barendrest, 1984; Parkes, 1986; Herz \& Garrison, 1998; Merrill \& McFadden, 2005), becoming excellent magnetostratigraphic markers for the time-span covered by the paleomagnetic record of the sites presented in this paper.

\section{Acknowledgements}

I am indebted to M. Cuadrado Woroszylo, D. Curzio and M. Silveira. They were very helpful during the fieldwork and palaeomagnetic sampling. Also I thank the University of Buenos Aires and CONICET for their support; J. L. Sáenz, A. Manero and G. Clifton for his friendship, continuous support and help in Río Gallegos, A. C. Sanguinetti de Bórmida was very supportive during the sampling in the northern Patagonian project (PMT-PICT0458). Several aspects of this research was supported by Agencia de Promoción Científica y Tecnológica, CONICET; National Geographic Society (Grant 5691-96); Logistic suort during the fieldwork was provided by Secretaría de Cultura de la provincia de Misiones, Museo Regional Juan P. Molina, Secretaría de Deportes de Santa Cruz, INTA and FOMICRUZ S.A. from Santa Cruz, Ariztizábal family for allowing to work in his Estancia at the Chico river. Paleomagnetic data were processed with IAPD and MAG88 programs developed by Torsvik (Norwegian Geological Survey) and E. Oviedo (University of Buenos Aires) respectively; Especially to H. Vizán for his useful comments and stimulating feedback. Additional thanks to all the fellows at the Institute for their fruitful discussion and invaluable help during this research.

\section{Conflicts of Interest}

The author declares no conflicts of interest regarding the publication of this paper.

\section{References}

Barendrest, R. W. (1984). Using Paleomagnetic Remanence and Magnetic Susceptibility Data for the Differentiation, Relative Correlation and Absolute Dating of Quaternary Sediments. In W. C. Mahaney (Ed.), Quaternary Dating Methods (pp. 101-140). Amsterdam: Elsevier. https://doi.org/10.1016/S0920-5446(08)70067-0

Bird, J. (1988). Travels and Archaeology in South Chile (246 p). Iowa City, IA: Iowa Uni- 
versity Press. https://doi.org/10.2307/j.ctt20h6v8q

Bogue, S. W., \& Merrill, R. T. (1992). The Character of the Field during Geomagnetic Reversals. Annual Review of Earth Science, 20, 181-219. https://doi.org/10.1146/annurev.ea.20.050192.001145

Burakow, K. S., \& Nachasova, I. E. (1990). Anomalous Behaviour of the Geomagnetic Field in the 1st Thousand Years B.P. Geomagnetic Field in Quaternary. Zipe 62, Postdam, DDR: Akademie der Wissenschaften der DDR, 135-138.

Clark, H. C., \& Kennet, J. P. (1973). Paleomagnetic Excursion Recorded in Latest Pleistocene Deep-Sea Sediments, Gulf of Mexico. Earth and Planetary Science Letters, 19, 267-274. https://doi.org/10.1016/0012-821X(73)90127-1

Coe, R. S., \& Glen, J. M. G. (2004). The Complexity of Reversals. In J. E. E. Channell, D. V. Kent, W. Lowrie, \& J. G. Meert (Eds.), Timescales of the Paleomagnetic Field (pp. 221-232). Washington DC: AGU. https://doi.org/10.1029/145GM16

Creer, K. M., \& Ispir, Y. (1970). An Interpretation of the Behaviour of the Geomagnetic Field during Polarity Transitions. Physics of the Earth and Planetary Interiors, 2, 283-293. https://doi.org/10.1016/0031-9201(70)90015-4

Creer, K. M., Tucholka, P., Valencio, D. A., Sinito, A. M., \& Vilas, J. F. (1983). Results from Argentina. In K. M. Creer, P. Tucholka, \& C. E. Barton (Eds.), Geomagnetism and Baked Clays and Recent Sediments (pp. 231-236). Amsterdam, Holland: Elsevier Publishers.

Dergachev, V. A., Raspopov, O. M., van Geel, B., \& Zaitseva, G. I. (2004). The "Sterno-Etrussia" Geoamagnetic Excursion around 2700 BP and Changes of Solar Activity, Cosmic Ray Intensity, and Climate. Radiocarbon, 46, 661-681. https://doi.org/10.1017/S0033822200035724

Gogorza, C. S. G., Di Tommaso, I., Sinito, A. M., Jackson, B., Nuñez, H., Creer, K., \& Vilas, J. F. (1998). Preliminary Results from Paleomagnetic Records on Lake Sediments from South America. Studia Geophysica and Geodaetica, 42, 12-29.

https://doi.org/10.1023/A:1023312104722

Gogorza, C. S. G., Sinito, A. M., Vilas, J. F., Creer, K., \& Nuñez, H. (2000). Geomagnetic Secular Variations over the Last 6500 Years as Recorded by Sediments from the Lakes of South Argentina. Geophysical Journal International, 143, 787-798. https://doi.org/10.1046/j.1365-246X.2000.00277.x

González, S., Sherwood, G., Bohnel, H., \& Schne, E. (1997). Palaeosecular Variation in Central Mexico over the Last 30000 Years: The Record from Lavas. Geophysical Journal International, 130, 201-219. https://doi.org/10.1111/j.1365-246X.1997.tb00999.x

Grondona, M. F. (1975). Pendiente del Océano Atlántico. In Geografía de la República Argentina. Hidrografía (VII, $2^{\circ}$ parte pp. 203-394). Buenos Aires, Argentina: Sociedad Argentina de Estudios Geográficos.

Gurarii, G. Z. (2005). Geomagnetic Field Reversals: Main Results and Basic Problems. Russian Journal of Earth Sciences, 7, ES3003. https://doi.org/10.2205/2005ES000175

Guskova, E. G., Raspopov, O. M., Piskarev, A. L., \& Dergachev, V. A. (2008). Magnetism and Paleomagnetism of the Russian Arctic Marine Sediments. In Proceedings of the 7th International Conference Problems of Geocosmos (pp. 380-385). St. Petersburg, Russia.

Herrero-Bervera, E., \& Coe, R. S. (1999). Transitional Field Behaviour during the Gilbert-Gauss and Lower Mammoth Reversals Recorded in Lavas from the Waianae cano, O'ahu, Hawaii, Journal of Geophysical Research, 104, 29157-29173.

https://doi.org/10.1029/1999JB900208 
Herz, N., \& Garrison, E. G. (1998). Geological Methods for Archaeology. New York: Oxford University Press.

Hoffman, K. A., \& Singer, B. S. (2004). Regionally Recurrent Paleomagnetic Transitional Fields and Mantle Processes. In J. E. E. Channell, D. V. Kent, W. Lowrie, \& J. G. Meert (Eds.), Timescales of the Paleomagnetic Field (pp. 233-243). Washington DC: AGU. https://doi.org/10.1029/145GM17

Kirschvink, J. L. (1980). The Least-Squares Line and Plane and the Analysis of Palaeomagnetic Data. Geophysical Journal International, 62, 699-718. https://doi.org/10.1111/j.1365-246X.1980.tb02601.x

Kochegura, V. V., \& Pisarevsky, S. A. (1994). Paleomagnetic Study of the Holocene and Late-Glacial Sediments of the North-Western Russia. In XXI International Union of Geodesy and Geophysics General Assembly (p. A173). Boulder, CO: Abstracts.

Laj, C., \& Channell, J. E. T. (2007). Geomagnetic Excursions. In Treatise of Geophysics (pp. 373-416). Amsterdam, Holland: Elsevier. https://doi.org/10.1016/B978-044452748-6.00095-X

Lund, S. P., Platzman, E., Thouveny, N., \& Camoin, G. (2007). Evidence for Two New Paleomagnetic Field Excursions 2,500 and 12,500 Years Ago from the South Pacific Ocean Region (Tahiti). American Geophysical Union, Fall Meeting 2007, Abstract ID: GP42A-05.

Lund, S. P., Platzman, E., Thouveny, N., Camoin, G., Yokoyama, Y., Matsuzaki, H. et al. (2008). Evidence for Two New Magnetic Field Excursions (11,000 and 13,000 Cal Yrs BP) from Sediments of the Tahiti Coral Reef (Maraa tract). American Geophysical Union, Fall Meeting 2008, Abstract ID: GP21B-0786.

Lund, S. P., Williams, T., Acton, G. D., Clement, B., \& Okada, M. (2001). Brunhes Chron Magnetic Field Excursions Recovered from Leg 172 Sediments. In L. D. Keigwin, D. Rio, G. D. Acton, \& E. Arnold (Eds.), Proceedings of the Ocean Drilling Program, Scientific Results (pp. 1-18). https://doi.org/10.2973/odp.proc.sr.172.216.2001

Mena, M., \& Nami, H. G. (2002). Distribución Geográfica de PGVs Pleistoceno Tardío-Holoceno obtenidos en sedimentos de América del norte y América del Sur. In XXI Reunión Científica de la Asociación Argentina de Geofísicos y Geodestas (pp. 213-218). Buenos Aires: Asociación Argentina de Geofísicos y Geodestas.

Merrill, R. T., \& McFadden, P. L. (1994). Geomagnetic Field Stability: Reversal Events and Excursions. Earth and Planetary Science Letters, 121, 57-69. https://doi.org/10.1016/0012-821X(94)90031-0

Merrill, R. T., \& McFadden, P. L. (2005). The Use of Magnetic Field Excursions in Stratigraphy. Quaternary Research, 63, 232-237. https://doi.org/10.1016/j.yqres.2005.02.007

Nami, H. G. (1994). Excursiones Geomagnéticas y Arqueología: Nuevos Datos y Perspectivas en la Patagonia Actas y Memorias del XI Congreso Nacional de Arqueología Argentina (Resúmenes). Revista del Museo de Historia Natural de San Rafael, XIII, 362-367.

Nami, H. G. (1995a). Holocene Geomagnetic Excursion at Mylodon Cave, Ultima Esperanza, Chile. Journal of Geomagnetism and Geoelectricity, 47, 1325-1332.

Nami, H. G. (1995b). Archaeological Research in the Argentinean Río Chico Basin. Current Anthropology, 36, 661-664. https://doi.org/10.1086/204413

Nami, H. G. (1999a). Possible Holocene Excursion of the Earth's Magnetic Field in Southern South America: New Records from Archaeological Sites in Argentina Earth Planets and Space, 51, 175-191. https://doi.org/10.1186/BF03352222

Nami, H. G. (1999b). Arqueología de la localidad arqueológica de Pali Aike, Cuenca del 
río Chico (provincia de Santa Cruz, Argentina). I. Las investigaciones arqueológicas. Praehistoria, 3, 189-201.

Nami, H. G. (1999c). Probable Middle Holocene Geomagnetic Excursion at the Red Rock Archaeological Site, California. Geofísica Internacional, 38, 239-250.

Nami, H. G. (2006). Preliminary Paleomagnetic Results of a Terminal Pleistocene/Holocene Record from Northeastern Buenos Aires Province (Argentina). Geofizika, 23, 119-141.

Nami, H. G. (2008). Paleomagnetic Results from the Urupez Paleoindian Site, Maldonado Department, Uruguay. Current Research in the Pleistocene, 25, 40-43.

Nami, H. G. (2011). New Detailed Paleosecular Variation Record at Santa Lucía Archaeological Site (Corrientes Province, Northeastern Argentina). Geofísica Internacional, 50, 9-21.

Nami, H. G. (2012). New Detailed Holocene Paleomagnetic Records with Anomalous Geomagnetic Field Bahavior in Argentina. Geoacta, 37, 83-116.

Nami, H. G. (2015). New Paleomagnetic Results and Evidence for a Geomagnetic Field Excursion during the Pleistocene-Holocene Transition at Pichincha Province, Ecuador. Geofísica Internacional, 54, 127-148. https://doi.org/10.1016/j.gi.2015.04.009

Nami, H. G., \& Mena, M. (2010). Geographical Distribution Analysis of Pleistocene/Holocene VGPs from North and South America. Eos Transactions AGU, 91, Abstract GP11C-03.

Nami, H. G., \& Sinito, A. M. (1991). Preliminary Paleomagnetic Results, the Campo Cerda Rockshelter, Province of Chubut, Argentina. Quaternary of South America and Antarctic Peninsula, 9, 141-151.

Nami, H. G., \& Sinito, A. M. (1993). Evidence of a Possible Excursion of the Geomagnetic Field Registered during the Late Holocene in the Province of Chubut, Argentina. Geoacta, 20, 9-26.

Nami, H. G., \& Sinito, A. M. (1995). Primeros resultados de los estudios paleomagnéticos en sedimentos de Cueva del Medio (Ultima Esperanza, Chile). Anales del Instituto de la Patagonia Serie Ciencias Humanas, 23, 135-142.

Nami, H. G., de la Peña, P., Vásquez, C., Feathers, J., \& Wurz, S. (2016). Paleomagnetic Results and New Dates from Late Pleistocene and Holocene Deposits from Klasies River Cave 1, South Africa. South African Journal of Science, 112, Article No. 2016-0051. https://doi.org/10.17159/sajs.2016/20160051

Nami, H. G., Vásquez, C. A., \& Durán, V. A. (2017). Detailed Early Holocene (10.3 cal kybp) Paleomagnetic Record with Anomalous Directions from Mendoza Province, Western Argentina. Latinmag Letters, 7, LL17-0702Rs.

Nami, H. G., Vásquez, C. A., Wadley, L., \& de la Peña, P. (2019). Detailed Paleomagnetic Record at Rose Cottage Cave, South Africa: Implications for the Holocene Geomagnetic Field Behavior and Chronostratigraphy. Submitted for publication.

Noël, M. (1975). The Palaeomagnetism of Varved Clays from Blekinge, Southern Sweden. Geologiska Föreningen i Stockholm Förhandlingar, 97, 357-367. https://doi.org/10.1080/11035897509454326

Nöel, M. (1977). The Late Weichselian Geomagnetic Event. Nature, 267, 181. https://doi.org/10.1038/267181a0

Noël, M., \& Tarling, D. (1975). The Laschamp Geomagnetic "Event”. Nature, 253, 705-707. https://doi.org/10.1038/253705a0

Ohno, M., Murakami, F., Komatsu, F., Guyodo, Y., Acton, G., Kanamatsu, T. et al. (2008). Paleomagnetic Directions of the Gauss-Matuyama Polarity Transition Record- 
ed in Drift Sediments (IODP Site U1314) in the North Atlantic. Earth, Planets and Space, 60, e13-e16. https://doi.org/10.1186/BF03352845

Orgeira, M. J., Beraza, L. A., Vizán, H., \& Vilas, J. F. A. (1990). Evidence for a Geomagnetic Field Excursion in the Late Pleistocene (Entre Ríos, Argentina). Quaternary of South America and Antarctic Peninsula, 6, 173-188.

Orgeira, M. J., Walter, A. M., Sinito, A. M., Vilas, J. F. A., \& Conti, C. (1996). New Evidence of an Excursion of the Geomagnetic Field Recorded in Late Pleistocene Sediments in Argentina. Journal of South American Earth Sciences, 9, 237-242. https://doi.org/10.1016/0895-9811(96)00009-0

Ortega-Guerrero, B., \& Urrutia-Fucugauchi, J. (1997). A Paleomagnetic Secular Variation Record from Late Pleistocene-Holocene Lacustrine Sediments from Chalco Lake, Basin of Mexico. Quaternary International, 43-44, 87-96. https://doi.org/10.1016/S1040-6182(97)00024-4

Parkes, P. A. (1986). Current Scientific Techniques in Archaeology. New York: St. Martin's Press, $190 \mathrm{p}$.

Petrova, G. N., \& Pospelova, G. A. (1990). Excursions of the Magnetic Field during the Brunhes Chron. Physics of the Earth and Planetary Interiors, 63, 135-143. https://doi.org/10.1016/0031-9201(90)90067-8

Pirazzolli, P. (1996). Sea-Level Changes in the Last 20000 Years. Chichester: John Wiley \& Sons.

Pospelova, G. A. (1981). Excursions of the Geomagnetic Field during Brunhes Epoch. Internationales Symposium, Aktuelle Probleme der Geomagnetischen Forschungm Veröffentlichungen des Zentralinstituts für Physik der Erde, 70, 245-261.

Pospelova, G. A. (1990). Excursions of the Brunhes Chron as the Base of Magnetochronostratigraphical Scale for the Quaternary. In Geomagnetic Field in Quaternary (No. 62, pp. 49-80). Postdam, DDR: Veröffentlichung.

Ransom, C. J. (1973). Magnetism and Archaeology. Nature, 242, 518-519. https://doi.org/10.1038/242518b0

Raspopov, O. M., Dergachev, V. A., Goos'kova, E. G., \& Morner, N. A. (2003). Visual Evidence of the Sterno-Etrussia Geomagnetic Excursion ( 2700 BP)? Geophysical Research Abstracts, 5, Article ID: 3208.

Ré, G. H., Mena, M., \& Vilas, J. F. (2008). Late Cenozoic Paleomagnetic Studies in Patagonia. In J. Rabassa (Ed.), The Late Cenozoic of Patagonia and Tierra Del Fuego (pp. 121-150). Rotterdam, Holland: Elsevier.

Roberts, A. P. (2008). Geomagnetic Excursions: Knows and Unknowns. Geophysical Research Letters, 35, L17307. https://doi.org/10.1029/2008GL034719

Sanguinetti de Bórmida, A. C. (2005). El Norpatagoniense. Expansión y límites: Evidencias arqueológicas, In A. Guiance (Ed.), La Frontera: Realidades y representaciones (pp. 111-126). Buenos Aires: Editorial Dunken.

Sinito, A. M., \& Nuñez, H. J. (1997). Paleosecular Variations Recorded on Lake Sediments from South America Journal of Geomagnetism and Geoelectricity, 49, 473-483. https://doi.org/10.5636/jgg.49.473

Sinito, A. M., Gogorza, C., Nami, H. G., \& Irurzun, M. A. (2001). Observaciones Paleomagnéticas en el Sitio Arqueológico Puesto Segundo (Misiones, Argentina). Anales de la Asociación Física Argentina, 13, 237-241.

Sinito, A. M., Nami, H. G., \& Gogorza, C. (1997). Analysis of Palaeomagnetic Results from Holocene Sediments Sampled at Archaeological Excavations in South America. Quaternary of South America and Antarctic Peninsula, 10, 31-44. 
Sylwan, C. A. (1989). Paleomagnetism, Paleoclimate and Chronology of Late Cenozoic Deposits in Southern Argentina (110 p). Stockholm, Sweden: Department of Geology, Stockholm University.

Tarling, D. (1983). Palaeomagnetism: Principles and Applications in Geology, Geophysics and Archaeology. New York: Chapman and Hall.

https://doi.org/10.1007/978-94-009-5955-2

Thouveny, N., \& Creer, K. M. (1992). Geomagnetic Excursions in the Past 60 ka: Ephemeral Secular Variation Features. Geology, 20, 399-402. https://doi.org/10.1130/0091-7613(1992)020<0399:GEITPK>2.3.CO;2

Thouveny, N., Creer, K. M., Smith, G., \& Tucholka, P. (1985). Geomagnetic Oscillations and Excursions and Upper Pleistocene Chronology. Episodes, 8, 180-182.

Trebino, L. G. (1987). Geomorfología y eución de la costa en los alrededores del pueblo de San Blas, provincia de Buenos Aires. Revista de la Asociación Geológica Argentina, $X L I I, 9-22$.

Urrutia-Fucugauchi, J., Lozano-García, S., Ortega-Guerrero, B., \& Caballero-Miranda, M. (1995). Paleomagnetic and Paleoenvironmental Studies in the Southern Basin of Mexico-II Last Pleistocene-Holocene Chalco Lacustrine Record. Geofísica Internacional, 34, 33-53.

Valencio, D. A., Sinito, A. M., Creer, K. M., Mazzoni, M. M., Alonso, M. S., \& Markgraf, V. (1985). Paleomagnetism, Sedimentology, Radiocarbon Age Determinations and Palynology of the Llao-Llao Area, Southwestern Argentina (lat. $41^{\circ} \mathrm{S}$, long. $71^{\circ} 30^{\prime} \mathrm{W}$ ): $\mathrm{Pa}-$ leolimnological Aspects. Quaternary of South America and Antarctic Peninsula, 3, 109-147.

Verosub, K., \& Banerjee, S. K. (1977). Geomagnetic Excursions and Their Paleomagnetic Record. Review of Geophysics, 15, 145-155. https://doi.org/10.1029/RG015i002p00145

Violante, R. A., Parker, G., \& Cavallotto, J. L. (2001). Evolución de las llanuras costeras del este bonaerense entre la bahía de Samborombón y la laguna Mar Chiquita durante el Holoceno. Revista de la Asociación Geológica Argentina, 56, 51-66.

Vitorello, I., \& Van Der Voo, R. (1977). Magnetic Stratigraphy of Lake Michigan Sediments Obtained from Cores of Lacustrine Clay. Quaternary Research, 7, 398-412. https://doi.org/10.1016/0033-5894(77)90030-8

Vizán, H., \& Azcuy, C. (2010). Is a Geomagnetic Field Excursion Stratigraphically Correlated to the Record of a Human Foot Print? Eos Trans AGU, 91, Abstract GP12A-03.

Watkins, N. D. (1972). Review of the Development of the Geomagnetic Polarity Time Scale and Discussion of Prospects for Its Finer Definition. Geological Society of America Bulletin, 83, 551-574. https://doi.org/10.1130/0016-7606(1972)83[551:ROTDOT]2.0.CO;2

Wiegank, F., Petrova, G. N., \& Pospelova, G. A. (1990). Magneto-Chronostratigraphic Scale Model, Brunhes Chron, Geomagnetic Field in Quaternary, Zipe 62, Postdam., DDR: Akademie der Wissnschafter der DDR, 169-177.

Woolin, G., Erickson, D. B., Ryan, B. F., \& Foster, J. H. (1971). Magnetism of the Earth and Climatic Changes. Earth and Planetary Science Letters, 12, 175-183. https://doi.org/10.1016/0012-821X(71)90075-6

Zhu, R. X., Coe, R. S., \& Zhao, X. X. (1998). Sedimentary Record of Two Geomagnetic Excursions within the Last 15,000 Years in Beijing, China. Journal of Geophysical Research, 103, 30323-30334. https://doi.org/10.1029/98JB02836 